\title{
North American Droughts of the Last Millennium from a Gridded Network of Tree-Ring Data
}

\author{
Celine Herweijer, Richard Seager, Edward R. Cook, and Julien Emile-Geay \\ Lamont-Doherty Earth Observatory, Columbia University, Palisades, New York
}

(Manuscript received 18 November 2005, in final form 19 June 2006)

\begin{abstract}
Drought is the most economically expensive recurring natural disaster to strike North America in modern times. Recently available gridded drought reconstructions have been developed for most of North America from a network of drought-sensitive tree-ring chronologies, many of which span the last $1000 \mathrm{yr}$. These reconstructions enable the authors to put the famous droughts of the instrumental record (i.e., the 1930s Dust Bowl and the 1950s Southwest droughts) into the context of $1000 \mathrm{yr}$ of natural drought variability on the continent. We can now, with this remarkable new record, examine the severity, persistence, spatial signatures, and frequencies of drought variability over the past millennium, and how these have changed with time.

The gridded drought reconstructions reveal the existence of successive "megadroughts," unprecedented in persistence (20-40 yr), yet similar in year-to-year severity and spatial distribution to the major droughts experienced in today's North America. These megadroughts occurred during a 400-yr-long period in the early to middle second millennium A.D., with a climate varying as today's, but around a drier mean. The implication is that the mechanism forcing persistent drought in the West and the Plains in the instrumental era is analagous to that underlying the megadroughts of the medieval period. The leading spatial mode of drought variability in the recontructions resembles the North American ENSO pattern: widespread drought across the United States, centered on the Southwest, with a hint of the opposite phase in the Pacific Northwest.

Recently, climate models forced by the observed history of tropical Pacific SSTs have been able to successfully simulate all of the major North American droughts of the last $150 \mathrm{yr}$. In each case, cool "La Niña-like" conditions in the tropical Pacific are consistent with North American drought. With ENSO showing a pronounced signal in the gridded drought recontructions of the last millennium, both in terms of its link to the leading spatial mode, and the leading time scales of drought variability (revealed by multitaper spectral analysis and wavelet analysis), it is postulated that, as for the modern day, the medieval megadroughts were forced by protracted La Niña-like tropical Pacific SSTs. Further evidence for this comes from the global hydroclimatic "footprint" of the medieval era revealed by existing paleoclimatic archives from the tropical Pacific and ENSO-sensitive tropical and extratropical land regions. In general, this global pattern matches that observed for modern-day persistent North American drought, whereby a La Niña-like tropical Pacific is accompanied by hemispheric, and in the midlatitudes, zonal, symmetry of hydroclimatic anomalies.
\end{abstract}

\section{Introduction}

Modern-day North America, especially the waterthirsty West, needs little reminder of the cost of drought: "water shortages" and "wildfires" are familiar midsummer season headlines, and tales of devastation from the 1930s Dust Bowl and 1950s Southwestern

Corresponding author address: Dr. Celine Herweijer, 4 Prince Albert Road, London NW1 7SN, United Kingdom.

E-mail: celine.herweijer@rms.com droughts are far from forgotten. As recently as 1998, widespread drought conditions returned to the American West and Plains, and another multiyear drought event commenced, persisting in the Northern Plains and western Canda-United States border to this day (Seager 2006, manuscript submitted to J. Climate, hereafter SEA). Applying conservative estimates based on relief payments alone, each year of drought costs U.S. \$6-8 billion (FEMA 1995, p. 2). Actual costs swell well above this figure as one considers the reality of direct impacts to agriculture, tourism and recreation, urban

DOI: 10.1175/JCLI4042.1

(C) 2007 American Meteorological Society 
water supply, energy production, transportation, and human health, along with the multitude of indirect impacts (i.e., employment, consumption levels, etc.). In economic terms, although hurricanes and tropical storms are the most frequent weather-related disasters in the United States, droughts (with the recent exception of Hurricane Katrina) are the most costly natural disasters (Ross and Lott 2003).

Clearly, with drought a common occurrence in North America, the establishment of a reliable early warning system would be invaluable. An improved understanding of the causes of drought and drought persistence is central to the development of improved methods of forecasting. Instrumental records of North American hydroclimate have enabled us to examine the last $150 \mathrm{yr}$ of drought history in detail (i.e., Woodhouse and Overpeck 1998; Cole et al. 2002; Fye et al. 2003; Seager et al. 2005b; Herweijer et al. 2006). In recent years, climate modeling has led the way to much progress in our understanding of the causes of North American drought. The notion that large-scale extratropical drought events in the American West and Plains are linked to variations of the coupled tropical climate system on seasonal to interannual scales has been demonstrated by the simulation of short droughts as a response to SST forcing (Trenberth et al. 1988; Mo et al. 1991; Trenberth and Branstator 1992; Atlas et al. 1993; Trenberth and Guillemot 1996; Sud et al. 2003; Lau et al. 2006). In each case, North American drought occurs during times of a La Niña-like tropical Pacific. On multiyear time scales, the link between tropical SSTs and persistent drought has been advanced by two separate simulations of the major North American droughts of the twentieth century (Schubert et al. 2004; Seager et al. 2005a) in ensembles of climate model simulations forced by the time history of observed SST. The model used by Seager et al. (2005a) has since been used to link tropical Pacific SSTs to the occurrence of three severe droughts in the mid- to late nineteenth century (Herweijer et al. 2006) and the recent "turn of the century" drought (SEA). SST forcing from a warm tropical Indian Ocean (i.e., Hoerling and Kumar 2003; Lau et al. 2006), and a warm tropical Atlantic (Schubert et al. 2004; Sutton and Hodson 2005), has also been linked to the promotion of North American drought. However, while all of these model studies agree that tropical Pacific SSTs are important for North American drought, to varying degrees they disagree on the relative roles of Pacific, Indian, and Atlantic SST forcing.

To expand our understanding of the nature and extent of long-term natural drought variability in North
America, the use of centuries-long, gridded annual tree-ring chronologies provides us with an important new tool (see also Cook et al. 1999, 2004). In this paper, using the recent "North American Drought Atlas" of Cook and Krusic (2004), we will place modern-day North American drought variability in the context of the last $1000 \mathrm{yr}$ of natural aridity changes. The drought atlas provides annual tree-ring drought reconstructions on a 286-point $2.5^{\circ}$ by $2.5^{\circ}$ gridded network of summer Palmer Drought Severity Index (PDSI; Palmer 1965) data, which extends as far back as 1 B.C. at some locations. PDSI is a widely used measure of meteorological drought over the United States (Heim 2002) and other land regions worldwide (Dai et al. 1997, 2004). The index incorporates both precipitation and temperature into a simple two-layer soil moisture reservoir model. It has a built-in persistence term that means the PDSI for a given month integrates current and several months of antecedent soil moisture conditions, and is also scaled to remove differences between regional climatologies. See Palmer (1965) for further details.

A wealth of existing paleoclimatic aridity indicators, including tree rings, lake levels, lake sediments, fire scars, and eolian depositional features, suggest a drier Plains and Southwest between A.D. 800 and 1400 (Swetnam 1993; Stine 1994; Forman et al. 1995; Muhs et al. 1996; Dean 1997; Laird et al. 1996, 1998; Woodhouse and Overpeck 1998; Fritz et al. 2000; Forman et al. 2001; Cook et al. 2004; Yuan et al. 2004), and a wetter period in the Little Ice Age (LIA) from A.D. 1400 until the 1800s [except for the major late-sixteenth-century drought (Stahle et al. 2000)]. In fact, the drought atlas data of Cook and Krusic (2004) indicate that the present multiyear drought in the western United States pales in comparison to a "medieval megadrought" that occurred from A.D. 900 to 1400. A further rigourous and extensive examination of the drought atlas is clearly warranted.

Here, by examining the drought atlas from A.D. 1000 onward, we seek to quantify how typical or different the major modern-day North American droughts are in comparison to the droughts of the last millennium. This gridded dataset enables us to explore, for the first time, the relative timing, spatial extent, and evolution of drought at these times. We will show that during the Medieval Climate Anomaly (MCA; defined here as A.D. 1000 to A.D. 1450), drought in the West tended to persist for several decades and longer, in comparison to the multiyear- to decade-long droughts of the LIA and modern times. Despite the longer persistence, the spatial pattern and severity of these medieval megadroughts, as measured by the PDSI depression in any 
one year, appear very much akin to their modern-day counterparts.

Our approach will be fourfold: 1) identify a set of criteria to systematically define episodes of widespread and persistent drought over the last $1000 \mathrm{yr}$, and determine how the severity of drought has changed with time; 2) examine the spatial distribution of drought and its persistence and perform a principal component analysis (PCA) to examine the dominant modes of North American drought variability, with a view toward identifying their causal mechanisms; 3) use both the multitaper method of spectral analysis and wavelet analysis to investigate the dominant frequencies of North American drought, and how these vary with time; and 4) examine the global context of the North American megadroughts of the MCA in the paleoclimate record and compare it with modern-day analogs. Such a detailed evaluation of North American hydroclimatic variability over the last millennium will aid our understanding of the range of natural drought variability in the region. The West has proven vulnerable to droughts in the nineteenth and twentieth centuries, and the current work should raise questions as to how it would fare if the degree of aridity typical of the medieval period were ever to return.

\section{The North American Drought Atlas PDSI data}

Full details of the PDSI data are found in Cook and Krusic (2004) and the supporting online materials (SOM) of Cook et al. (2004). The $2.5^{\circ}$ latitude by $2.5^{\circ}$ longitude grid of summer PDSI values was reconstructed from tree rings using the point-by-point regression (PPR) method (Cook et al. 1999, 2004). Calibration with the instrumental PDSI grid was performed over the fixed 1928-78 period. Variance restoration was applied to correct for the artificial declines in PDSI variability with time due to the time-varying regression models used. Cook et al. (2004, and SOM) show that the calibration/verification statistics are highly significant across almost all grid points back to A.D. 1300, and significant $(p<0.05)$ for at least $75 \%$ of the grid points back to A.D. 800. This implies that the PDSI reconstructions are useful from A.D. 800 on. We focus our analyses on the reconstructions back to A.D. 1000, some 106 grid points. This cutoff point was chosen as a compromise between examining as many years of "useful" data as possible, and as many grid points as possible with continuous reconstructions (a requirement for the PCA analysis). This option was preferred to the alternative approach of optimal interpolation from A.D. 800 on, a method that would introduce further uncertainty to the reconstructions.
We conducted a "frozen grid" analysis to determine whether the "A.D. 1000 onward" subset of grid points is a good representation of the drought variability implied by the full grid. The PDSI averaged over the "West" (defined henceforth as $25^{\circ}-50^{\circ} \mathrm{N}, 95^{\circ}-25^{\circ} \mathrm{W}$ ) based only on the 106 grid points available in A.D. 1000 was compared to that based on the time-varying set of grid points that increases up to 156 in A.D. 1380 and is constant thereafter (the full grid). At annual resolution, the correlation between the two time series from A.D. 1000 to 2003 is 0.96 , increasing to 0.98 after 7 -yr low-pass filtering. Clearly, excluding the potential for increased resolution with time does not degrade the fidelity of the A.D. 1000 onward PDSI record as an index of drought severity in the West.

\section{Defining the droughts of the last $1000 \mathrm{yr}$}

Looking simply at annual PDSI averaged over the West, it is impressive how prominent the change in drought variability is before and after the mid-1400s (Fig. 1). The medieval megadrought of Cook et al. (2004) is an epoch of elevated aridity in the mean, with extensive (20-40 yr) periods of persistent drought (e.g., 1130-70 and 1220-1300) interrupted occasionally by shorter periods of PDSI variability more reminiscent of the latter half of the millennium (e.g., 1080-1120 and $1170-1220) .{ }^{1}$ It is the duration of these dry spells, not their severity, that stands out in a comparison against the droughts of modern times. The midnineteenth-century (or Civil War) drought, the Dust Bowl, the 1950s drought, and the most recent one (beginning in 1998) all reach the severity of the medieval droughts but had none of the persistence. In contrast, the Little Ice Age interval had no droughts of that severity.

Herein, the definition of a "drought" implies that two conditions are met: 1 ) the annual PDSI in the West is negative and does not deviate from this for more than two successive years (this defines the persistence threshold); 2) the $\mathrm{DAI}^{2}<-1$ in North America must be

\footnotetext{
${ }^{1}$ The dramatic jump from one of the most severe individual year droughts in 1258 back to normal in 1259 coincides with the massive volcanic eruption of 1258 or 1259 , the location of which is unknown (Stothers 2000; Oppenheimer 2003; Emile-Geay et al. 2007). Volcanic dust reduces surface solar irradiance, which, it has been suggested on the basis of model experiments, induces an E1 Niño-like response (Mann et al. 2005; see also Clement et al. 1996). An induced E1 Niño in 1258-59 could be a reason for the dramatic interruption of the midthirteenth-century drought.

${ }^{2}$ Drought Area Index (DAI) is a simple count of the number of gridpoint reconstructions that exceed a given PDSI threshold (i.e., here $<-1$ ) in any given year, converted to a percentage.
} 


\section{Drought Atlas PDSI in the West \\ a. $\mathrm{AD} 1000$ to $\mathrm{AD} 1470$}

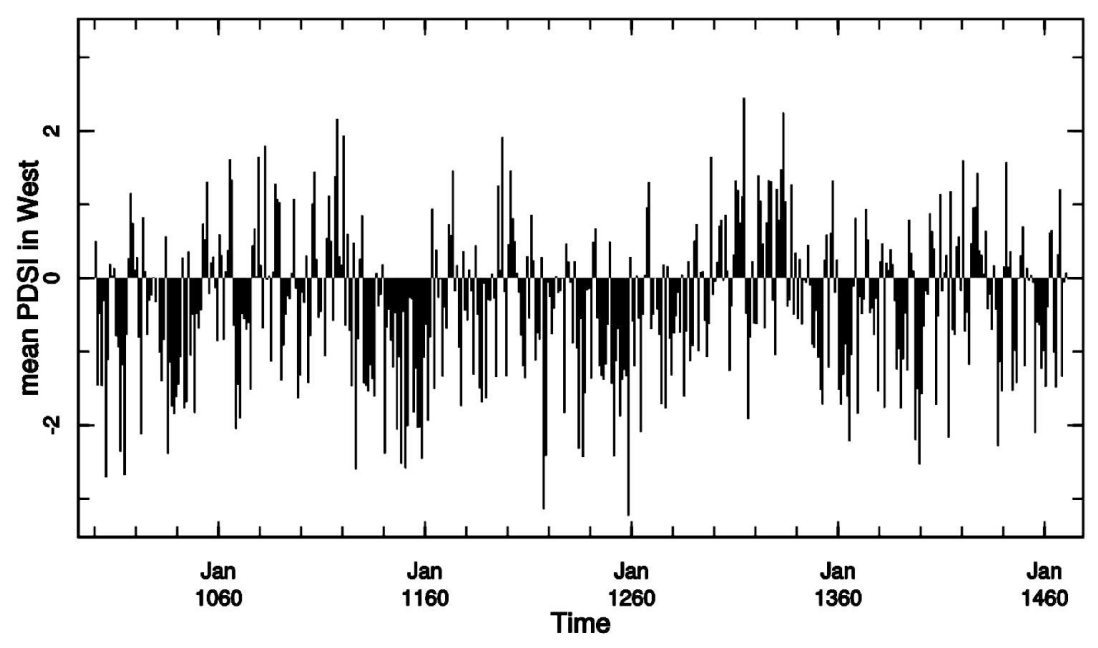

b. $\mathrm{AD} 1470$ to $\mathrm{AD} 2003$

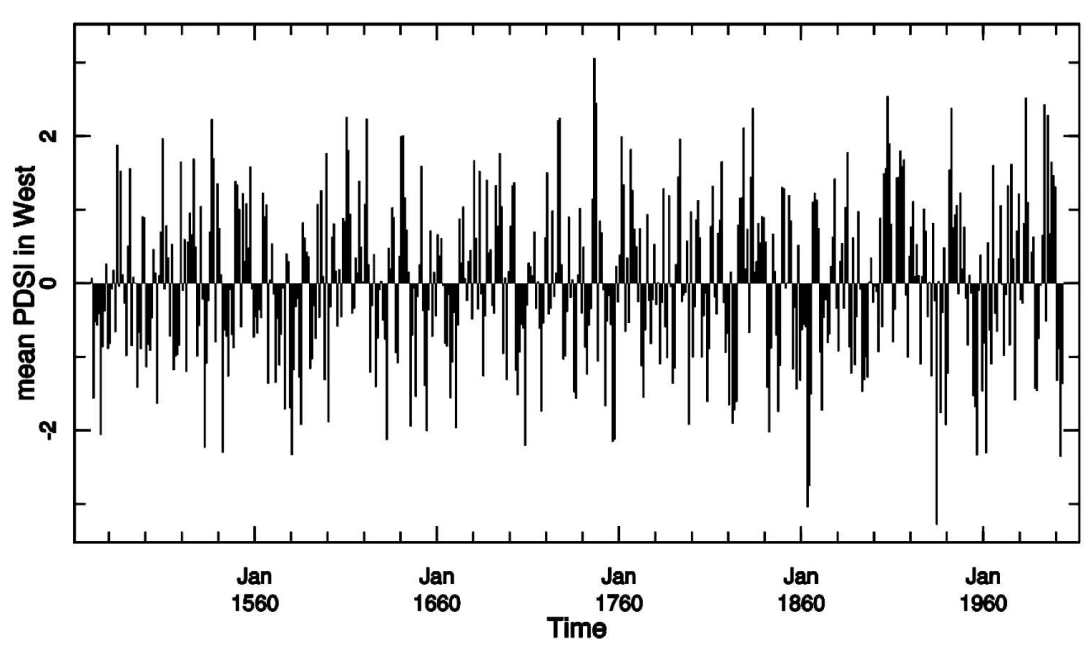

FIG. 1. Two distinct eras of drought variability highlighted by the mean annual PDSI in the West.

greater than the mean value (DAI $<-1: \sim 28 \%$ ) over the last $150 \mathrm{yr}$ (this defines the spatial scale threshold). Equipped with this definition, one can compare the major droughts of the MCA (Fig. 2) and their modern-day counterparts (Fig. 3). It appears that there is no striking difference between the spatial patterns of drought occurring at these times. In both cases, dry conditions are widespread across the continent. The drought centers are in the continental interior, either in the Southwest and Rockies, farther eastward in the Plains (including the Canadian Plains), or both. Moist conditions generally appear in southern Mexico, the Northwest, and the Northeast. Section 4 will provide a more in-depth examination of this.

To first order, the severity of drought in any one given year is also comparable between the modern (Fig. 3) and MCA droughts (Fig. 2). What is striking is that, during the MCA, the PDSI frequently remained below zero, with only modest interruptions for decades, while, during the modern day, droughts last at most several 


\section{MCA droughts}

AD 1021-1051
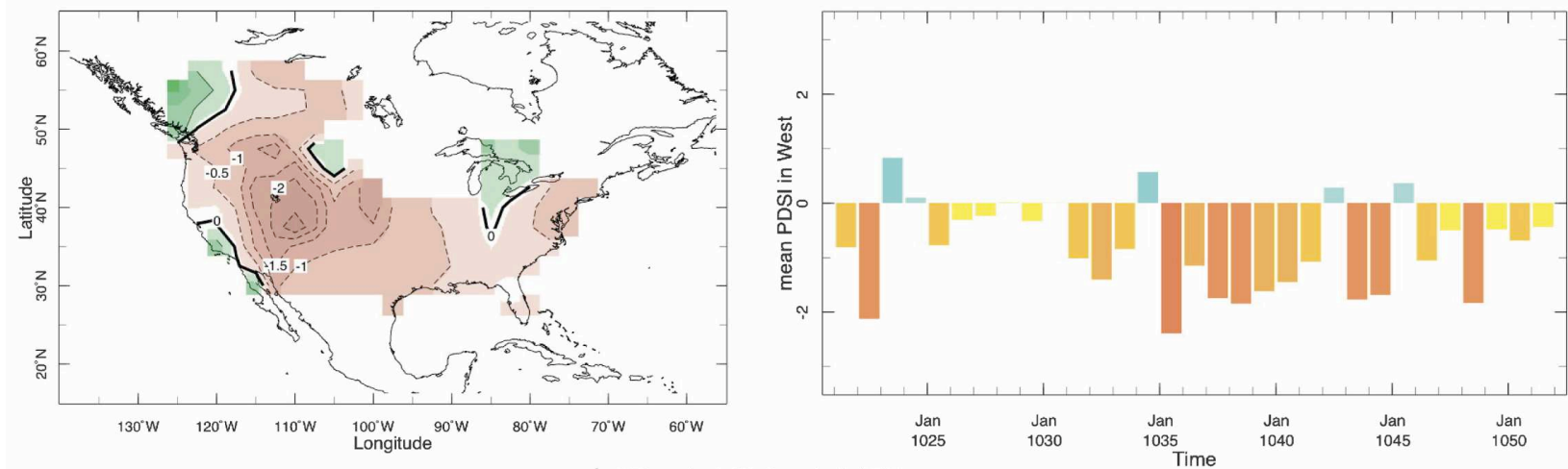

AD 1130-1170
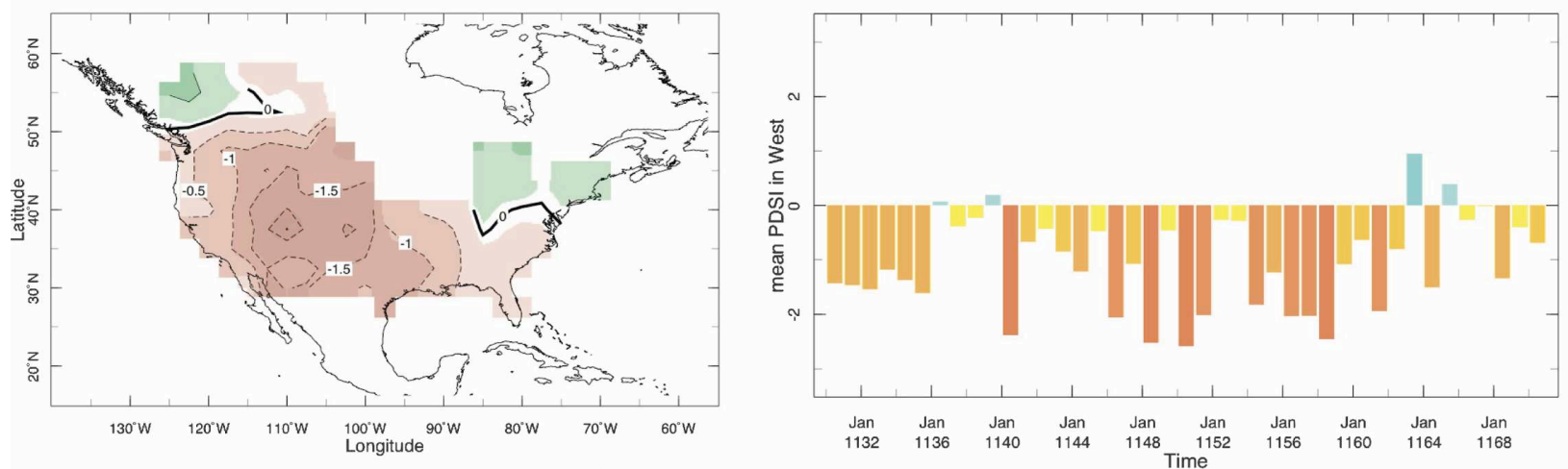

AD 1240-1265
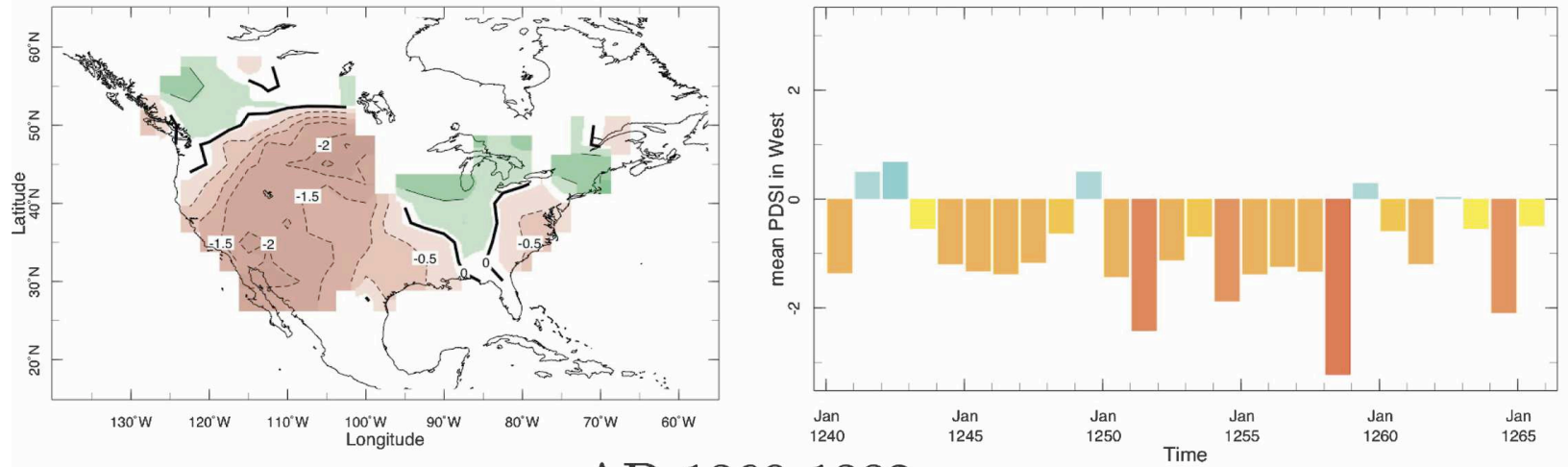

AD 1360-1382
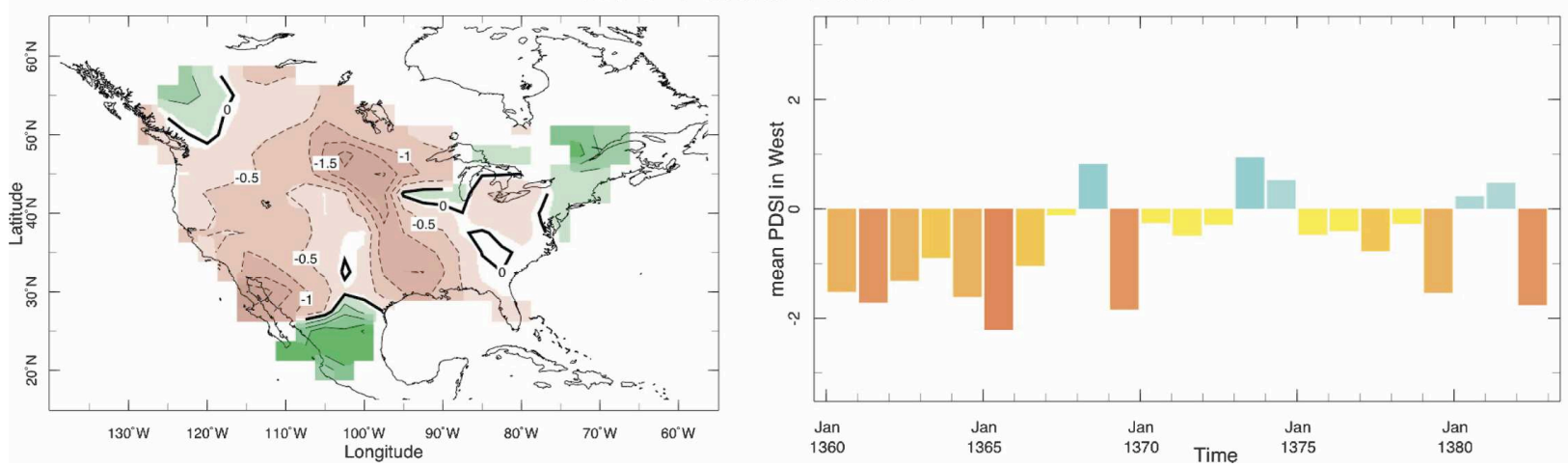

FIG. 2. Droughts of the MCA: spatial distribution and PDSI history over the West. As defined by the criteria outlined in section 3. 


\section{Modern-day droughts}

AD 1855-1865
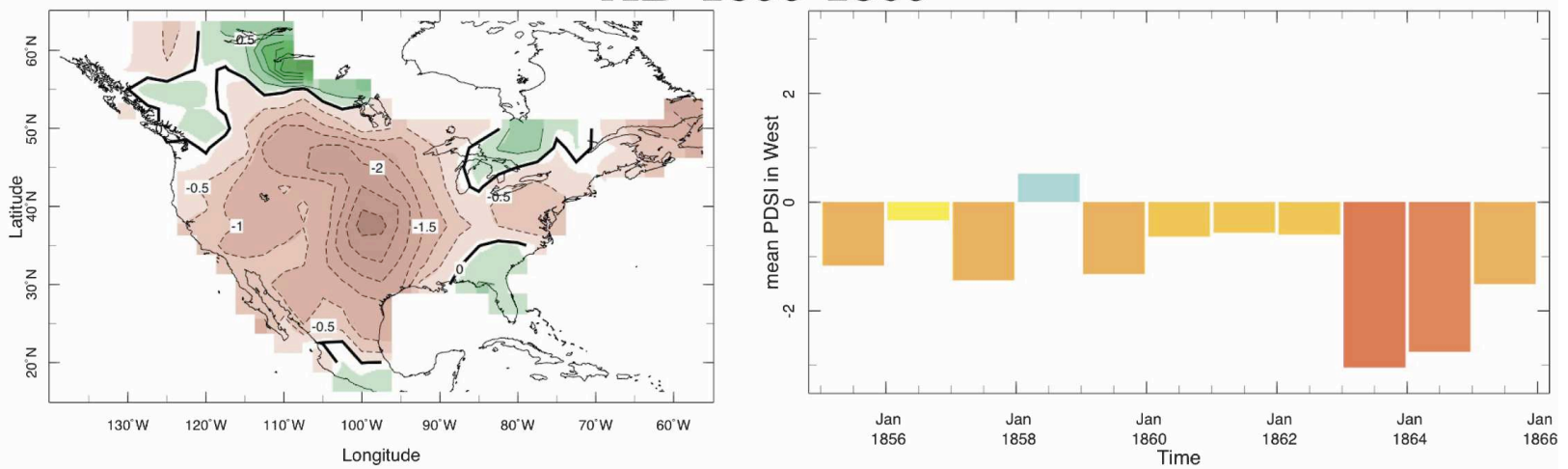

AD 1889-1896
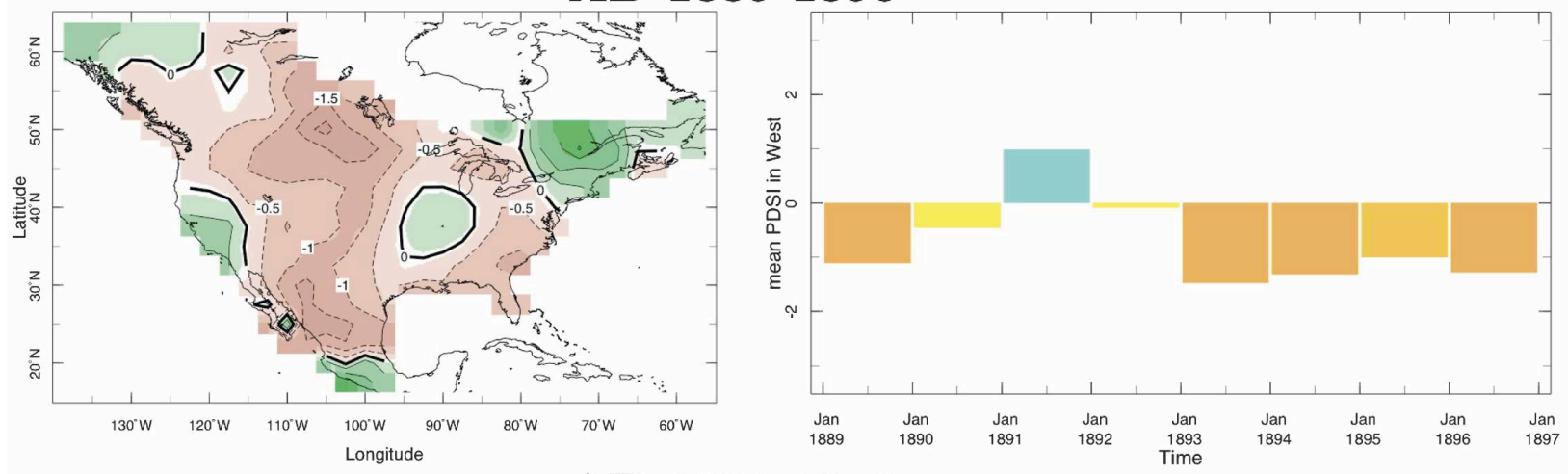

AD 1931-1940
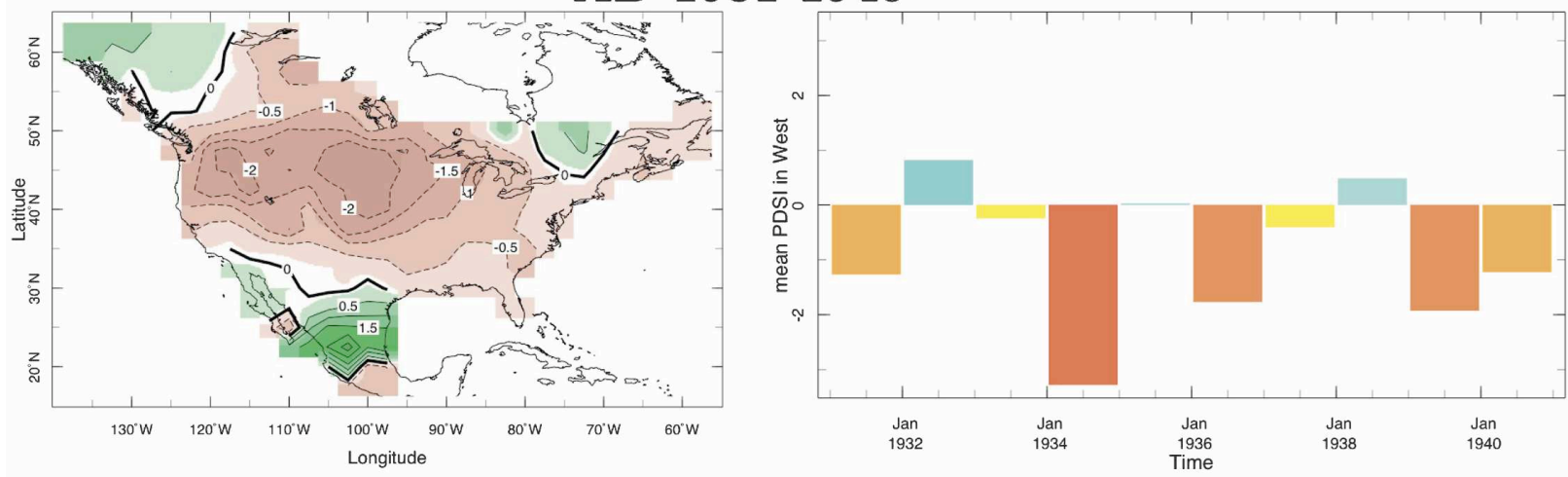

AD 1950-1957
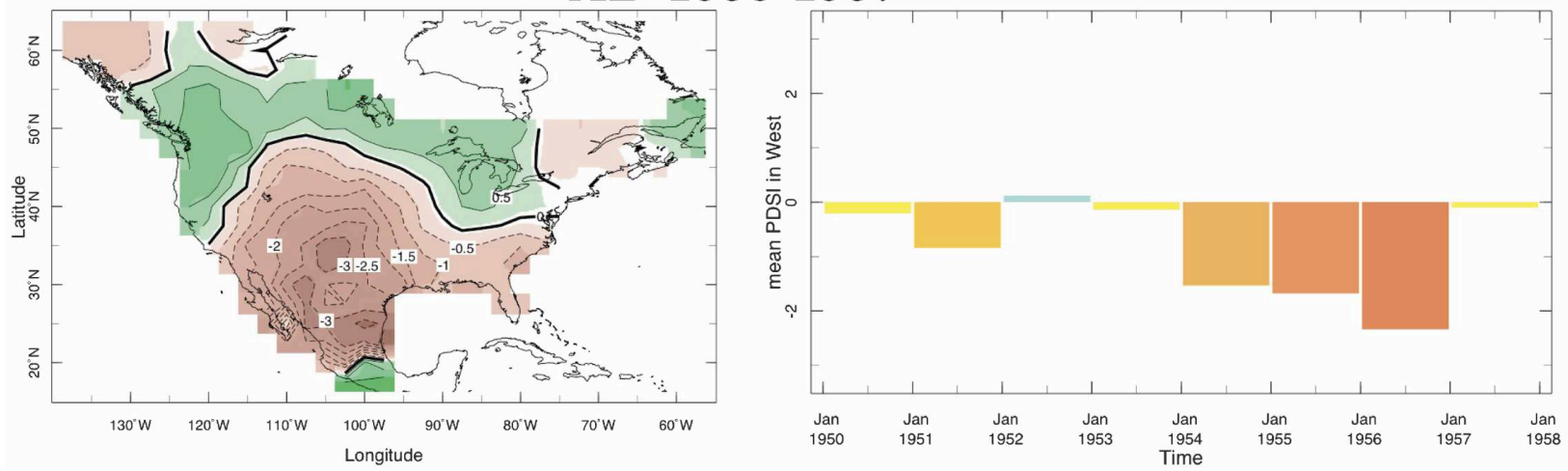

FIG. 3. Same as in Fig. 2, but for droughts of modern times. 

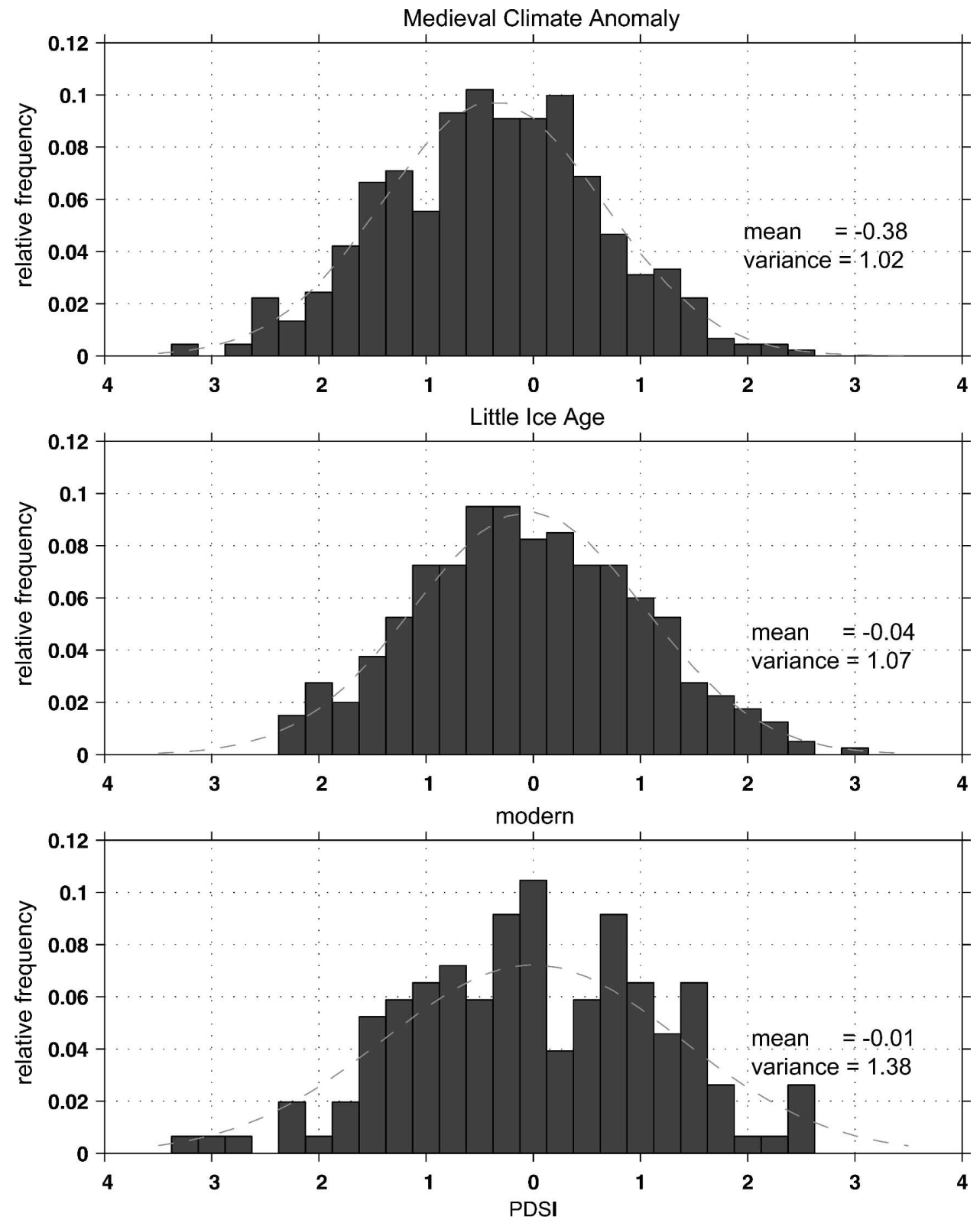

FIG. 4. Relative frequency histograms of the mean PDSI in the West during the MCA (A.D. 1000-1450), the LIA (A.D. 1451-1850), and the modern period (A.D. 1851-2003). The dashed line represents a normal probability density function with the same mean and variance as each of the respective time series.

years. Figure 4 shows the relative frequency histograms of the mean PDSI in the West over three periods: the MCA (A.D. 1000-1450), the LIA ${ }^{3}$ (A.D. 1451-1850), and the modern period (A.D. 1851-2003). All of the distri-

\footnotetext{
${ }^{3}$ It is acknowledged that the use of the terms MCA and LIA is widespread, yet often lacking in any accepted definition (see Bradley et al. 2003). The dates chosen here simply correspond to two periods, which fall within the defined ranges available in literature, of distinctly different North American hydroclimate in the drought atlas.
}

butions are close to Gaussian, but the MCA is around a negative mean. Similar variances between the histograms suggest that the climate was varying much as today, yet around a different mean: a drier mean in the case of the MCA. Furthermore, a difference histogram between the MCA and modern times (not shown) convincingly highlights that in the MCA it is both the modest and the more severe negative PDSI values that become more common. In summary, while the annual severity of drought conditions in the West is comparable between modern and medieval times, the MCA is a 


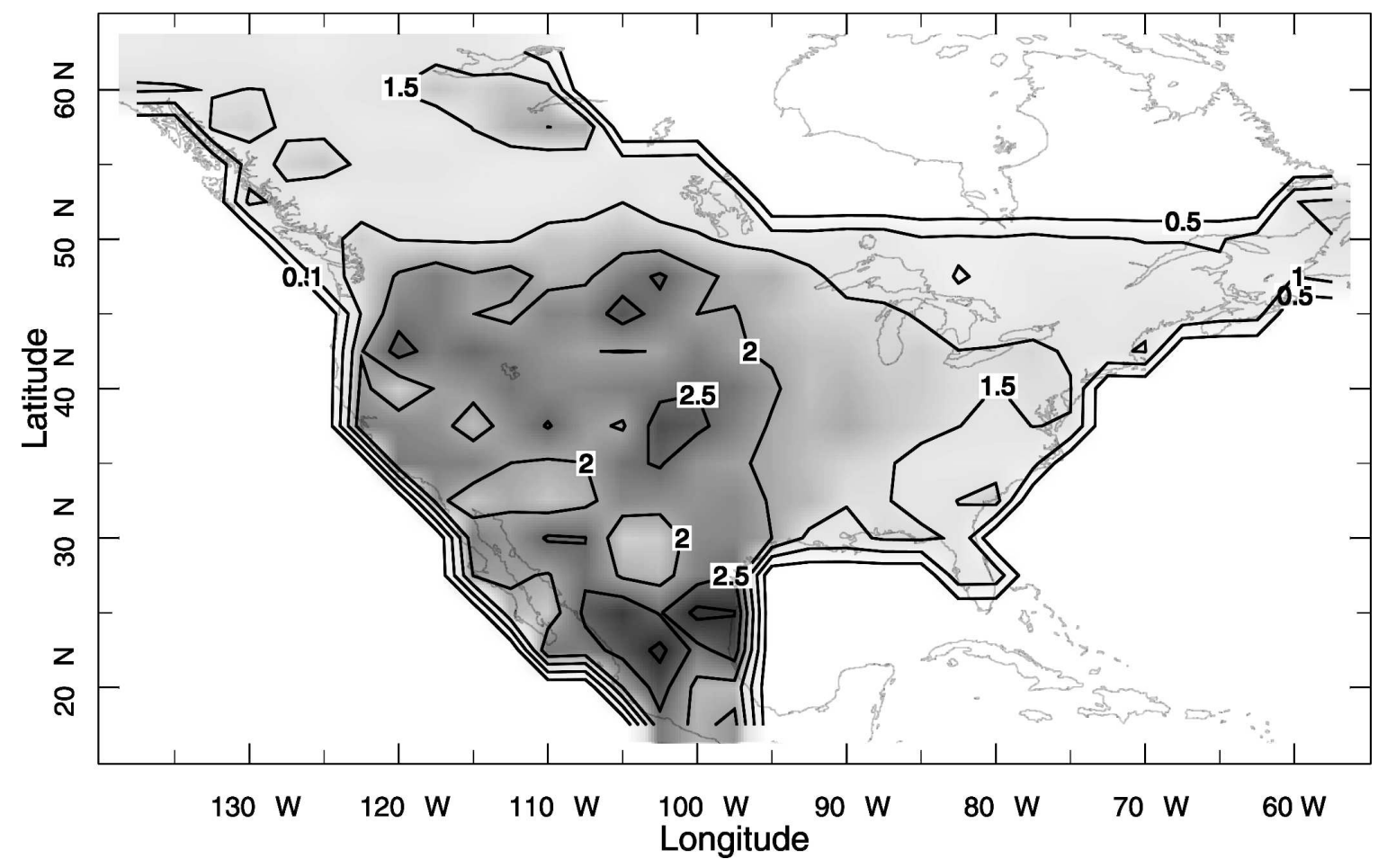

FIG. 5. PDSI variance map. Corresponds to the period from A.D. 1000 to 2003 . The outermost contour highlights the edge of the region over which PDSI data are available.

period of enhanced aridity characterized by megadroughts ${ }^{4}$ that persist for several decades.

\section{Spatial and temporal patterns of North American drought variability}

\section{a. Variance and regions of drought persistence}

The distribution of PDSI variance field from A.D. 1000 to 2003 is shown in Fig. 5. The highest PDSI variance is in the western United States. Noticeably, the centers of maximum variance largely correspond to the drought centers in the MCA (Fig. 2) and modern-day (Fig. 3) droughts. The relatively flat distribution of the PDSI variance is expected and reflects the fact that the PDSI normalizing constants are used to make the PDSI values independent of the local climatologies on which they are based.

Along with the distribution of PDSI variance, it is also important to consider where the different frequencies of drought variability occur. The PDSI data were 7-yr low-pass filtered to form decadal components,

\footnotetext{
${ }^{4}$ The term megadrought has previously been used to describe the multidecade-long, widespread, and severe eighth- and latesixteenth-century droughts in North America (Woodhouse and Overpeck 1998; Stahle et al. 2000; Stahle et al. 2002).
}

high-pass filtered $(<3 \mathrm{yr})$ to form interannual components, and bandpass filtered to form interannual E1 Niño-Southern Oscillation (ENSO) scale components (i.e., 3-7 yr) and multidecadal time-scale components (i.e., 7-40 yr). Figure 6 shows the ratio of filtered PDSI variance in different frequency bands relative to the unfiltered PDSI variance. High-frequency variability is highest over the coastal regions of the West and Southeast, where the climatological precipitation is highest, but contributes at most $15 \%$ of the total annual PDSI variance in the Interior states. The continental Interior region of maximum overall PDSI variance is dominated by decadal- (and lower frequency) scale fluctuations, accounting for over $40 \%$ of the variability in the Interior domain. In support of this, the lagged correlation of the PDSI values as a function of space also highlights that drought perisistence is greatest in the continental Interior region (not shown). Some of the low-passed PDSI variability is actually ultralow-frequency change. Using a bandpass filter to isolate periods between 7 and $40 \mathrm{yr}$, the contribution of the ultralow-frequency fluctuations $(>40 \mathrm{yr})$ is shown to be important in the Interior region (Fig. 6, bottom right). Thus, drought variability in the continental interior is accounted for by decadal, multidecadal, and even longer frequencies, while drought variability in the Pacific Northwest re- 

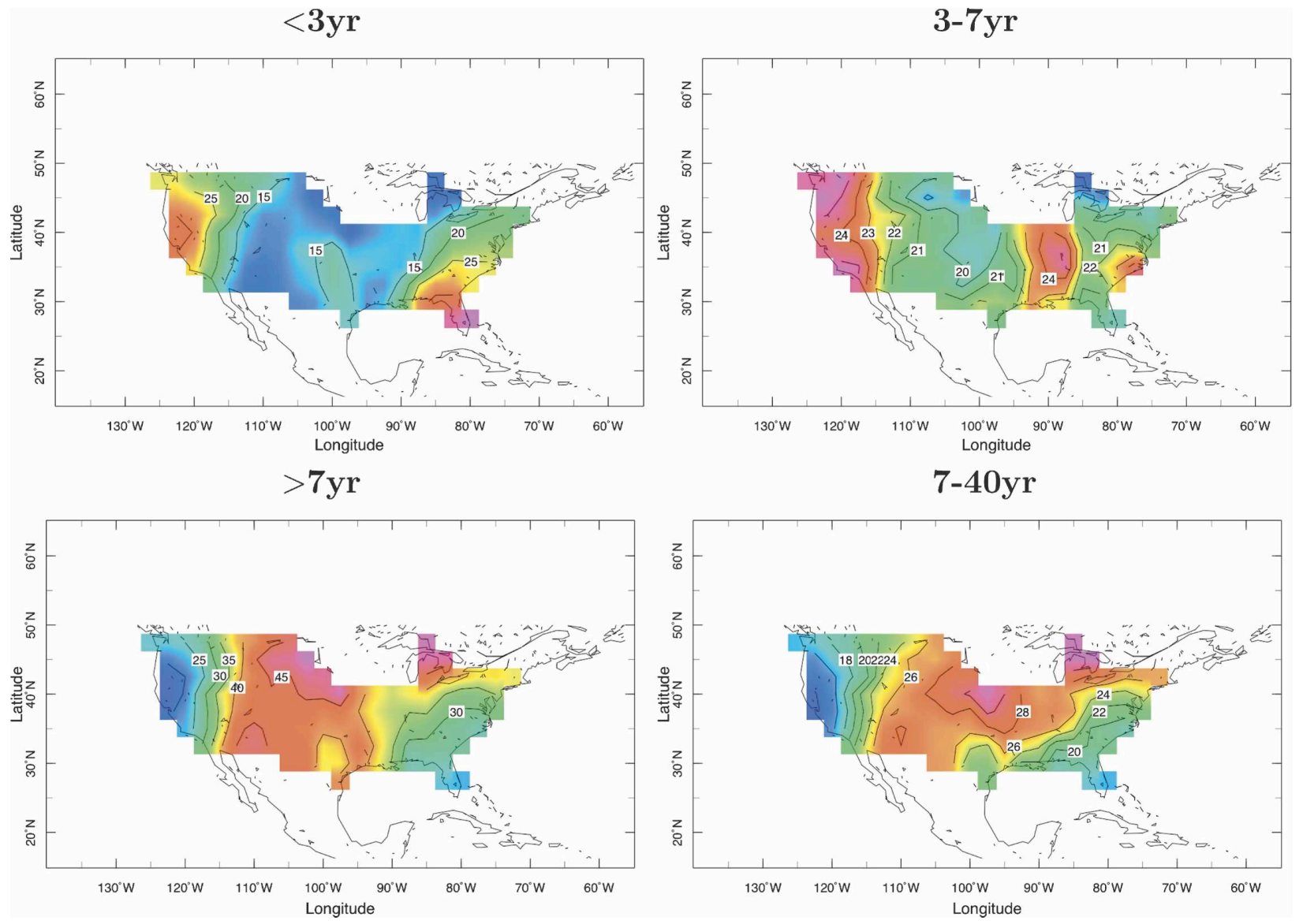

FIG. 6. Percent of PDSI variance in different frequency bands. Only the frozen grid region of PDSI values with a continuous record from A.D. 1000 onward is shown (a requirement of the filtering method).

gion of maximum local PDSI variance is dominated more by ENSO-scale and higher frequencies.

\section{b. Rotated principal component analysis}

Rotated principal component analysis (RPCA) is used to examine the natural drought patterns in the North American Drought Atlas. We use the orthogonal varimax rotation method (Kaiser 1960), which retains orthogonality between the resulting factors. While it can be argued that orthogonal factors are physically unrealistic, a comparison of varimax and oblique promax rotation factors for gridded summer drought reconstructions from 1700 to 1978 by Cook et al. (1999) indicates that the orthogonal solution is an adequate representation of the regional summer drought factors in the United States. We perform the RPCA on the frozen grid of PDSI values that reflects continuous records from A.D. 1000 onward.

Figure 7 shows the rotated empirical orthogonal functions (REOFs) over the A.D. 1000-2003 reconstruction period. There are three unrotated EOFs that ac- count for a significantly higher proportion of variance than the rest and are well separated according to both Preisendorfer's Rule N (Preisendorfer 1988) and North's rule of asymptotic errors (North et al. 1982). The varimax rotation is performed on these three leading EOFs. Karl and Koscielny (1982) and Cook et al. (1999) have both demonstrated that over the same North American domain, several more regional drought factors can be justifiably resolved by rotating more EOFs. Here, in contrast, we chose to focus our attention on the well-separated, large-scale structures of North American drought variability represented by the leading three structures.

The three rotated structures are primarily monopolar and indicate coherence over three large sectors of the United States. REOF1, accounting for 33\% of the variance, is monopolar across the continental Interior, with centers in the Southwest and Rockies, and weak tendencies to the opposite sign in the Northwest and Northeast. This all-U.S. pattern is akin to the precipitation pattern associated with interannual ENSO vari- 


\section{Rotated EOF analysis from A.D. 1000-2003 \\ REOF1, 0.32 \\ REOF2, 0.16}

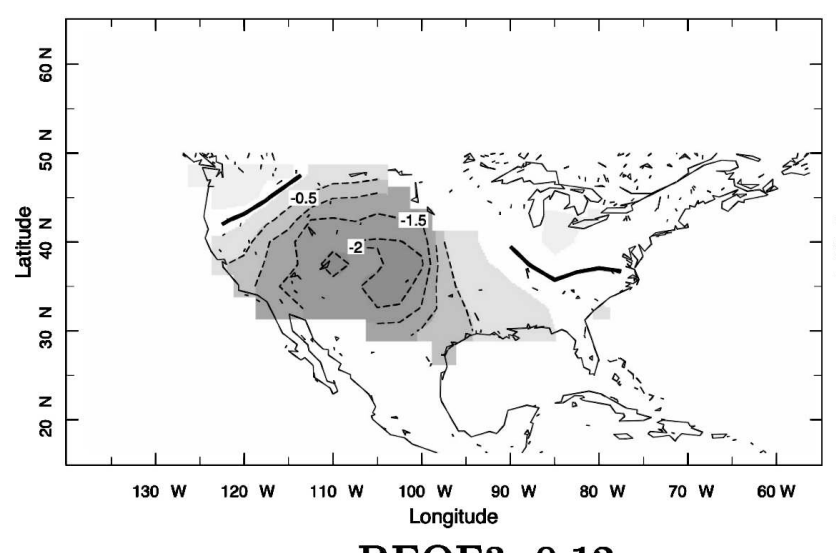

REOF3, 0.12

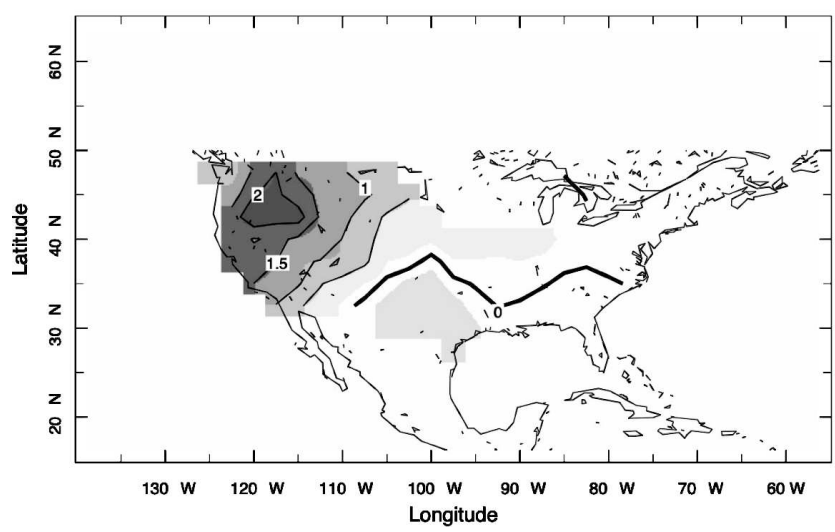

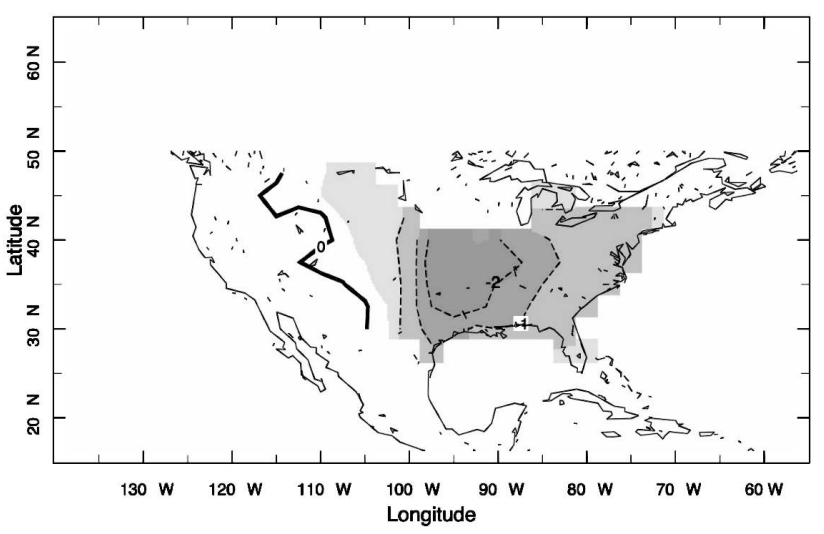

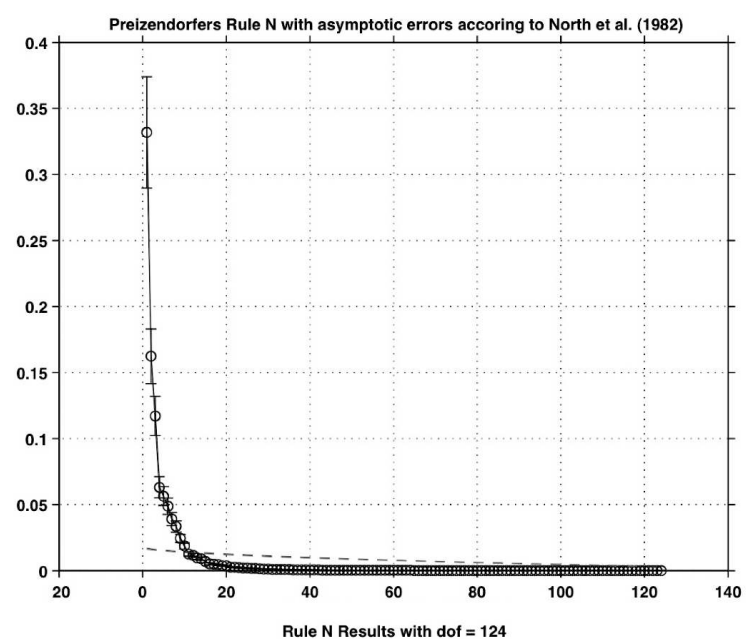

FIG. 7. Reconstructed summer drought varimax factors for North America (A.D. 1000-2003). The fractional variance explained by each structure is indicated by each map. A plot of the Preisendorfer's Rule N with asymptotic errors according to North et al. (1982) indicates the existence of three physically distinct structures. The three leading components (PC1, PC2, and PC3) explain $61 \%$ of the total variance in the PDSI data.

ability (i.e., Seager et al. 2005a). The two other retained structures explain $16 \%$ and $12 \%$ of the variance, respectively, and consist of monopolar patterns with regional centers in the Plains/Mississippi Valley (REOF2) and the Pacific Northwest (REOF3). These patterns are needed, in addition to REOF1, to fully explain the spatial patterns of the major droughts of the MCA and modern day displayed in Figs. 2 and 3 (Table 1). Most often loadings are dominated by REOF1 (i.e., the Southwest/southern Rockies droughts of A.D. 1021-51, 1130-70, and 1950-57), or spread between two or three codominant patterns representing regional drought in the Plains/Mississippi and/or Northwest.

An examination of the unrotated PCA solution reveals a monopolar "all-North America" pattern (EOF1) followed by an east-west dipolar partem (EOF2; not shown). A 1-point correlation centered at the east or west dipole maxima reveals no anticorrelation with the opposing dipole center and points to the artificiality of the east-west dipole mode. Essentially, the dipole that emerges in the unrotated case appears to be a classic example of the unrotated analysis forcing an unphysical spatial pattern orthogonal to the first all-North America pattern. The rotation does not requires orthogonal spatial patterns and instead gives rise to monopolar structures. The structure of the PDSI variance field (Fig. 5), which is rather flat with a maximum in the driest regions of the continental Interior and to the west, again points to the conclusion that the east-west dipole is an artifact of the unrotated analysis. 
TABLE 1. Contribution of principal rotated factors to the major droughts of the MCA and modern day.

\begin{tabular}{lccc}
\hline \hline $\begin{array}{c}\text { Drought interval } \\
\text { (year A.D.) }\end{array}$ & \% RPC 1 & \% RPC 2 & $\%(-)$ RPC 3 \\
\hline $1021-51$ & 52 & 22 & 26 \\
$1130-70$ & 56 & 22 & 22 \\
$1240-65$ & 57 & 14 & 29 \\
$1360-82$ & 23 & 46 & 21 \\
$1855-65$ & 43 & 43 & 14 \\
$1889-1996$ & 64 & 27 & 9 \\
$1931-40$ & 16 & 33 & 51 \\
$1950-57$ & 57 & 17 & 26 \\
\hline
\end{tabular}

The RPCA analysis was repeated on the "pre-1470" period characterized by multidecadal length droughts and the "post-1470" period of shorter multiyear to decadal droughts. In both instances, similar solutions are obtained to the A.D. 1000-2003 analysis, suggesting that the leading modes of spatial variability do not change with time (not shown). This, and the similarity of the spatial patterns of drought variability in the modern era and the MCA (Figs. 2 and 3), suggests a common causal mechanism.

For the instrumental era, one can explore the underlying global ocean-atmosphere context of the leading spatial modes of North American drought. Correlations of the leading RPCs with the global sea surface temperature anomaly (SSTA) and sea level pressure anomaly (SLPA) fields from 1856 onward are shown in Fig. 8. The SSTA data are the extended optimally interpolated Meteorological Office Historical Sea Surface Temperature (MOHSST5) dataset (Kaplan et al. 2003), and the SLP data correspond to the optimally interpolated Comprehensive Ocean-Atmosphere Data Set (COADS; Kaplan et al. 2000). A correlation coefficient of 0.17 or higher is required for significance at the $95 \%$ level. The leading spatial mode is clearly linked to interdecadal "ENSO-like" variability ${ }^{5}$ and appears to be the only mode related to the global climate system, although RPC2 may have a weak link to the North Atlantic Oscillation.

In summary, the results of the RPCA analysis strongly suggest that the tropical Pacific has been the

\footnotetext{
${ }^{5}$ Zhang et al. (1997) coined the use of the term ENSO-like to describe the pattern of SSTAs linked to the low-frequency time component of the leading spatial mode of global SSTA variability that bears much spatial resemblance to the interannual ENSO signature. The most obvious distinctions are that the interdecadal pattern does not have an SST variability maximum in the eastern equatorial Pacific (as explained by Hazeleger et al. 2004) and is less equatorially confined than the interannual ENSO pattern. Herein, the use of the term ENSO-like refers to this low-frequency component of variability.
}

dominant driver of North American drought over the last $1000 \mathrm{yr}$. This conclusion is based on the similarity of the spatial patterns of medieval and modern droughts, the similar frequency distribution of PDSI in the two periods, and the correlation of RPC1 to ENSO during the instrumental period. It also fits in neatly with the well-established link between persistent La Niña-like conditions and North American drought over the modern era (Trenberth et al. 1988; Trenberth and Branstator 1992; Cole et al. 2002; Hoerling and Kumar 2003; Schubert et al. 2004; Fye et al. 2003; Seager et al. 2005a,b; Huang et al. 2005; Herweijer et al. 2006). The implication is that the megadroughts of the MCA were forced by protracted La Niña-like conditions in the tropical Pacific. Unlike the modern day, these La Niñalike conditions may have persisted for periods of decades on end.

\section{c. Spectral analysis}

In this section we use both the multitaper method (MTM) of spectral analysis and wavelet analysis (WA) to examine in more detail the dominant frequency modes in the drought atlas data, and how these vary with time. We perform these analyses on the time series of mean PDSI in the West (see Fig. 1) for the complete record (A.D. 1000-2003), the pre-1470 period (i.e., A.D. 1000-1470), and the post-1470 period (i.e., A.D. 14702003).

The MTM method for spectral estimation has been widely applied to problems in climate-related signal analysis, including analyses of instrumental data and paleoclimatic proxy data (i.e., Berger et al. 1991; Lall and Mann 1995; Mann et al. 1995a,b; Mann and Lees 1996; Mommersteeg et al. 1995; Park and Maasch 1993; Yiou et al. 1997; etc.). We use the modified MTM procedure of Mann and Lees (1996) that is more suited to analysis of climatic time series than the traditional, strictly harmonic approach. Information from the harmonic peak test of the conventional MTM procedure is retained, but peaks, both harmonic or anharmonic (i.e., narrowband "quasi oscillatory" or intermittent oscillatory signals), are tested for significance relative to the empirically estimated global red noise background [see discussion in Mann and Lees (1996)]. MTM involves a premultiplication of the data by orthogonal tapers constructed to minimize the spectral leakage due to the finite length of the time series. The choice of bandwidth parameter $p$ and number of tapers $K$ represents the trade-off between spectral resolution and the stability or variance reduction properties of the spectral estimate [see discussion in Ghil et al. (2001)]. In practice, the number $K$ of tapers should be no less than $2 p-1$ to provide usefully small spectral leakage (i.e., Park 
RPC1:

SSTA

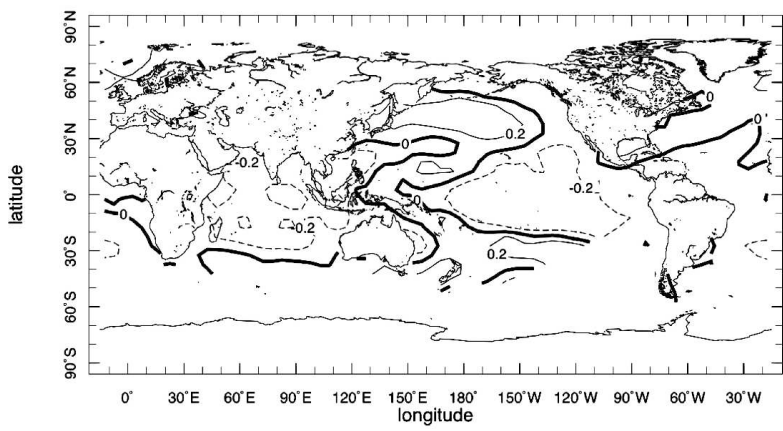

RPC2:

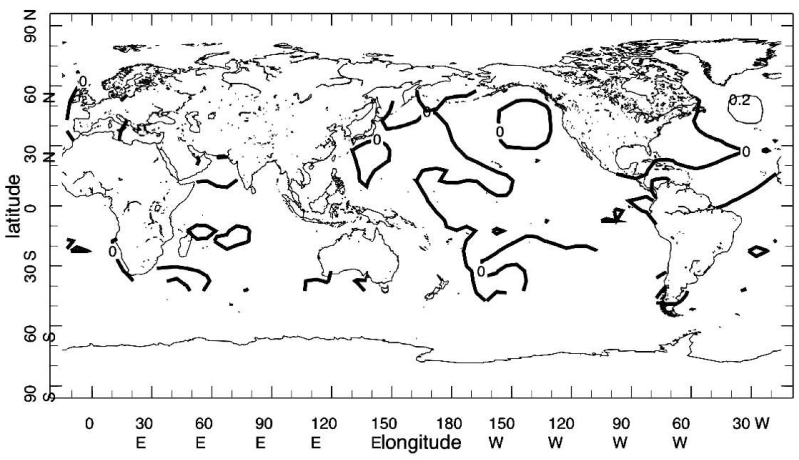

RPC3:

SSTA

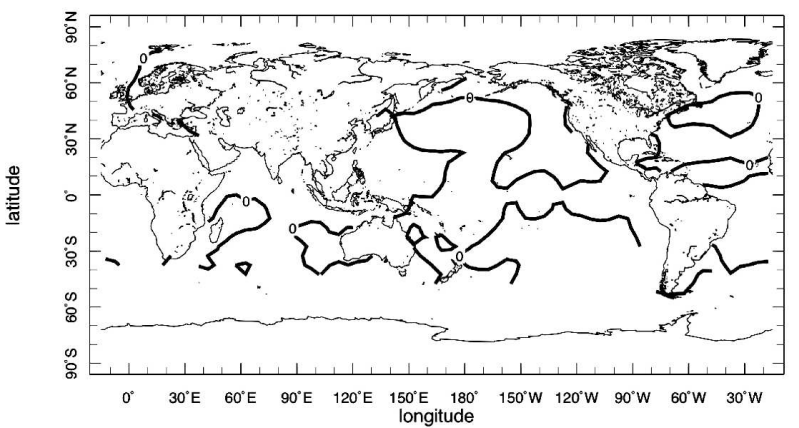

SLPA

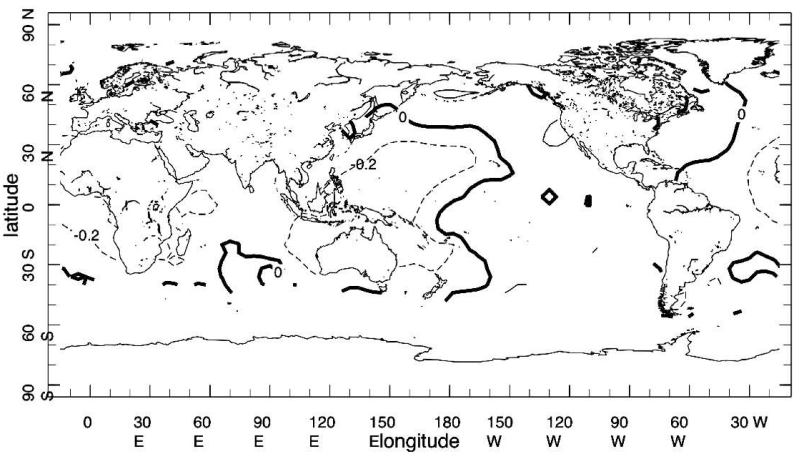

SLPA

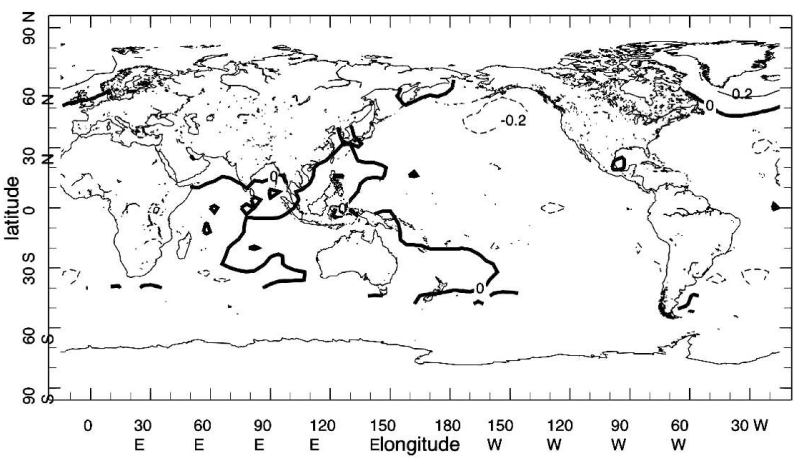

SLPA

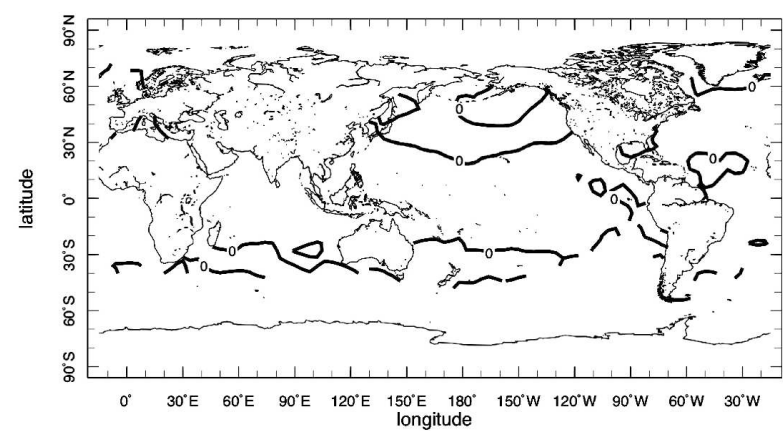

FIG. 8. The global circulation linkages to the dominant spatial modes of North American summer drought variability: field correlations between the leading RPCs and (left) SSTA and (right) SLPA over the instrumental period. The correlations correspond to the the years between 1856 and 2003 (SSTA) and 1856 and 1991 (SLPA). RPC1 is the only mode with a statistically significant recognizable global pattern.

1987). Here we use the bandwidth parameter $p=2$ and $K=3$ tapers as the best compromise for a time series of a few hundred points in length (i.e., pre- and post-A.D. 1470) to resolve distinct climate signals (e.g., ENSO and decadal-scale variability) with the benefit of reduced variance [see discussion in Mann and Park (1993)].

The MTM analysis of the period from A.D. 1000 onward is shown in Fig. 9. Two signals are significant well above the $99 \%$ level, one centered at 0.009 cycle $\mathrm{yr}^{-1}$ (approximately a 110 -yr period), the other, an interan-

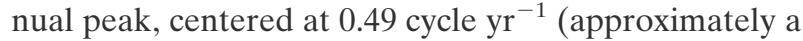
2.0-yr period). An ultralow-frequency variation that cannot be distinguished from a trend is also isolated as significant at the $99 \%$ level relative to the estimated red noise background. There are several peaks in the spectral estimate within the interannual ENSO band $(0.5>$ $f>0.13$ cycle $\mathrm{yr}^{-1}$, or $2.0<T<7.6 \mathrm{yr}$ ), and two independent bidecadal peaks (corresponding to periods of 22 and $18 \mathrm{yr}$ ) that are statistically significant, but only at the $95 \%$ level. 


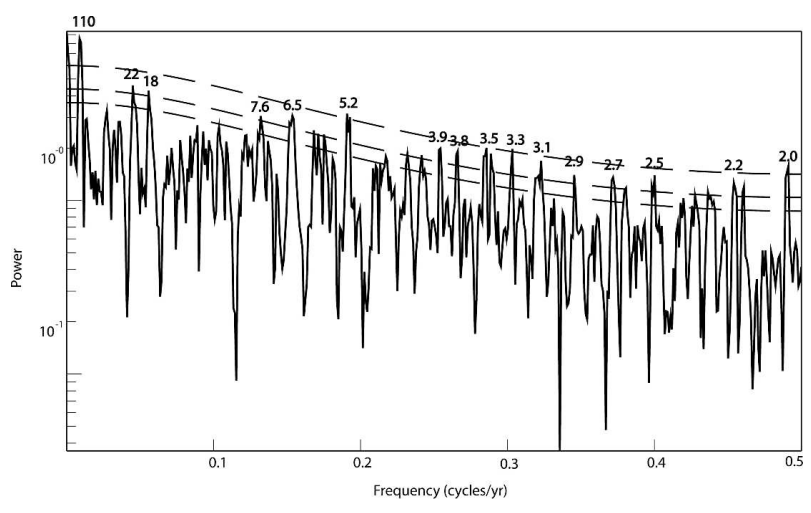

FIG. 9. High-resolution MTM spectrum of the mean West PDSI time series from A.D. 1000 to 2003 . The associated $90 \%, 95 \%$, and $99 \%$ significance levels for $N=1204$ annual samples are shown by the three dashed curves, in this order, from the lowest to the highest curve in the figure. See text for a detailed assessment of the significance of these peaks. The bandwidth parameter is $p=$ 2 , and $K=3$ tapers were used.

Repeating this analysis on a subdomain of the dataset, from A.D. 1000 to 1470 , reveals that interrannual-scale variability in the West did not die down in the medieval era of elevated aridity and megadroughts (Fig. 10, top). Two signals are significant well above the $99 \%$ significance level, one in the interannual ENSO band (approximately a 2.7-yr period), and one with centennial-scale bandwidth, again centered at 0.009 cycle $\mathrm{yr}^{-1}$ (roughly a $110-\mathrm{yr}$ period). A further eight signals in the interannual ENSO band are significant above the $95 \%$ significance level. No statistically significant power in the bidecadal range is observed, but peaks

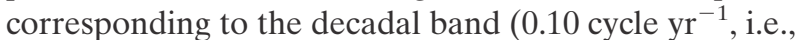

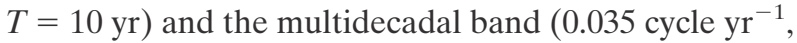
i.e., $T=29 \mathrm{yr}$ ) are significant, though only at the $95 \%$ level. From A.D. 1470 to 2003 (Fig. 10, bottom), the MTM analysis reveals that the centennial peak is no longer statistically significant, and that the signals above the $99 \%$ significance level all fall within the interannual ENSO band. Bidecadal peaks (i.e., $T=22 \mathrm{yr}$ and $18 \mathrm{yr}$ ) and a multidecadal peak (i.e., $T=35 \mathrm{yr}$ ) are only significant at the $90 \%$ level.

Wavelet analysis of this dataset allows us to investigate how the dominant time scales of drought variability change with time [see Gray et al. (2003) for a previous application of WA to tree-ring records in the United States]. We use a Morlet wavelet, normalized by $1 / \sigma^{2}\left[\sigma^{2}=\right.$ the variance of the time series (i.e., the mean PDSI in the West); see Torrence and Compo (1998) for a detailed discussion of wavelet analysis]. The wavelet spectra for the period from A.D. 1000 to 2003 is shown in Fig. 11. In agreement with the MTM analysis, interannual variability exists throughout the last millen- nium. Bidecadal variability is stronger, and statistically significant at the $95 \%$ level, in the latter half of the millennium (Fig. 12, bottom). In the pre-1470 period of megadroughts and elevated aridity in the mean, centennial-scale variability is evident, with some statistically significant strength also in the decadal and multidecadal bands (Fig. 12, top). As with the MTM, centennial variability is largely absent in the post- 1470 period, with the exception of a hint of the centennial band in the more arid modern period (Fig. 12, bottom). Consequently the centennial-scale variability should be treated with caution since only four realizations of it, during the medieval period, occur.

The presence of a bidecadal rhythm in western North American drought variability has been noted in the past (Mitchell et al. 1979; Currie 1981; Stockton et al. 1983; Currie 1984a,b; Cook et al. 1997). In particular, Cook et al.'s (1997) Singular Spectrum Analysis (SSA) of the western DAI from gridded drought reconstructions from A.D. 1700 to 1978 indicates a primary 22.2-yr peak and a secondary 19.2-yr peak, which are noted to be close to the Hale solar magnetic and lunar tidal periods. We make no inference as to the cause of the bidecadal signal here but simply point out its existence in the spectral analysis of western PDSI in the period from A.D. 1470 onward. Even more pronounced is the appearance of a centennial peak in both the MTM analysis and wavelet analysis. In the MTM analysis, this peak is dominant in the A.D. 1000-1470 spectrum (Fig. 10, top), yet disappears in the spectrum corresponding to the post- A.D. 1470 data (Fig. 10, bottom). The WA, which enables decomposition of PDSI data into a frequency-time domain, once again suggests that the centennial fluctuations are in fact peculiar to the first half of the millenium. Cook et al. (1997) propose that a centennial cycle may be a modulation that arises through the interaction of the 22- and 18-yr bidecadal periods. However, our analyses suggest that the centennial cycle is most prominent in the arid first half of the millennium, a time when the bidecadal rhythm is not statistically significant, and least prominent in the latter half of the millennium when the bidecadal rhythm is at its strongest.

Centennial-scale drought variability has previously been noticed in paleoaridity reconstructions of the last millennium in the United States (i.e., Yu and Ito 1999), Mexico (Hodell et al. 2001), and China (Hameed et al. 1983; Clegg and Wigley 1984; Hu and Feng 2001). Such centennial variability has also been linked to solar forcing (i.e., Yu and Ito 1999; Hodell et al. 2001). Spectral analysis of the Lean et al. (1995) solar reconstruction from A.D. 1600 onward indicates most power in the 70100 -yr Gleissberg solar cycle, followed by the 22- and 


\section{A.D.1000-1470}

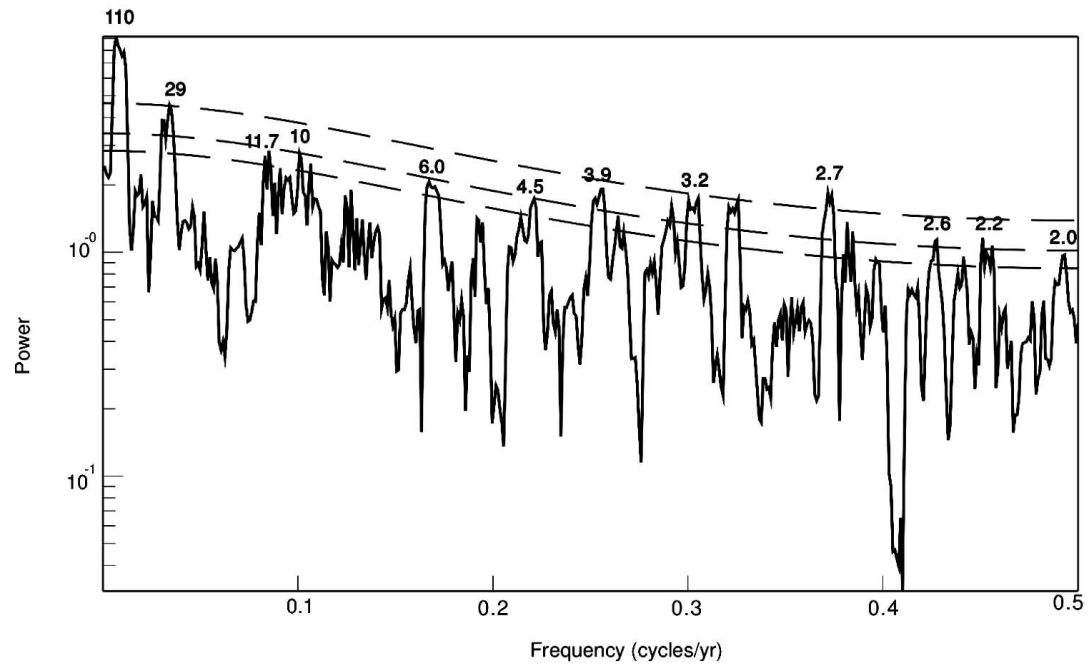

A.D. 1470-2003

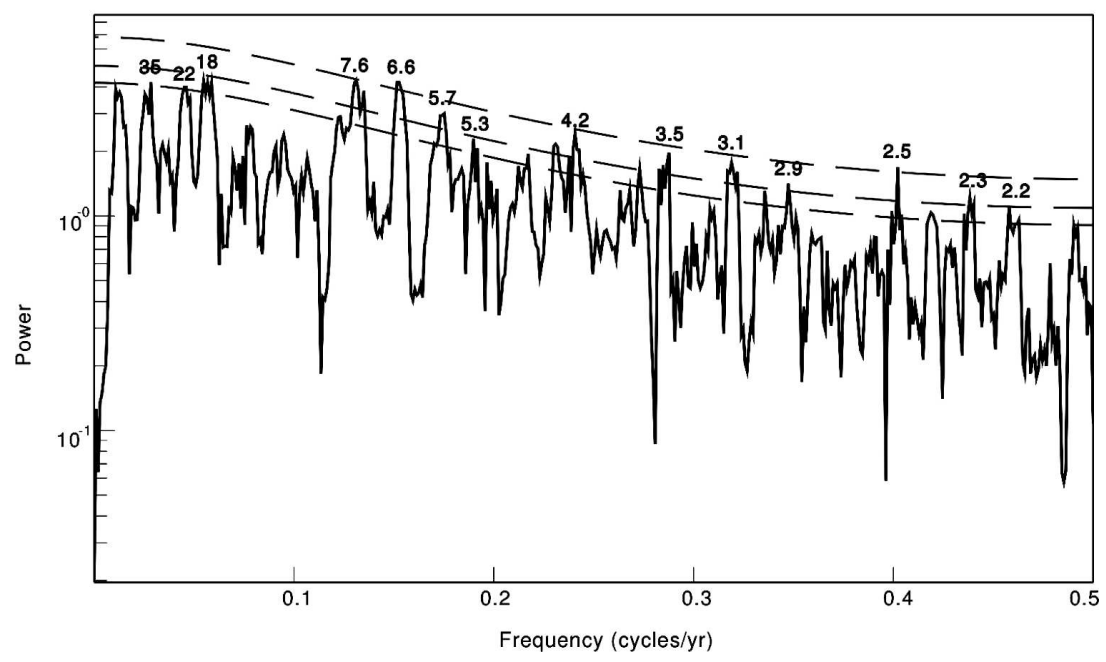

FIG. 10. Same as in Fig. 9, but for the mean West PDSI time series from (top) A.D. 1000 to 1470 and (bottom) A.D. 1470 to 2003.

11-yr sunspot cycles (Lohmann et al. 2004). Furthermore, the A.D. 1000-1998 wavelet spectra of the Bard et al. (2001) ${ }^{10} \mathrm{Be}$ solar irradiance reconstruction scaled to the Lean et al. (1995) changes over the last $400 \mathrm{yr}$, as used by Crowley (2000), displays a centennial peak, statistically significant at the $95 \%$ level, with the most energy (not shown). However, the centennial peak, as expected, does not diminish during the latter half of the millennium. A cross wavelet transform (XWT) of the solar and PDSI data over the common A.D. 1000-1998 period shows that in the centennial band, the solar and PDSI data have high common power with the expected phase relationship at times when the PDSI data show significant centennial power (not shown). In this case, the two time series are antiphased in the mean with a time lag of $14 \mathrm{yr}$, such that high solar irradiance corresponds to North American drought. Interestingly, $14 \mathrm{yr}$ is the time it takes for the tropical Pacific to respond to solar irradiance in the model experiments of Mann et al. (2005). The wavelet coherence (WTC) spectra does not confirm this relationship (not shown), signifying that further work is needed on this matter.

In summary, while the timing between the centennial solar cycle and the centennial North American drought rhythm does match, to infer causality is another matter. Furthermore, we emphasize caution on overinterpreting the apparent disappearance of the centennial cycle in the midfifteenth century. 
a. West PDSI: 1000-2003 A.D.
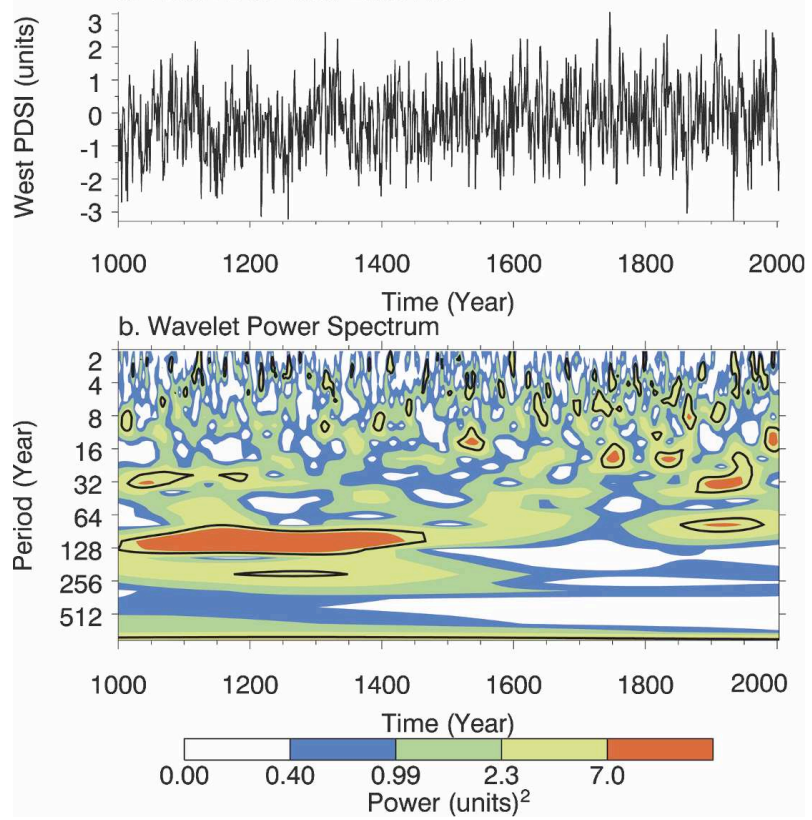

FIG. 11. (a) Time series of mean West PDSI for 1000-2003. (b) The wavelet power spectrum. The contour levels are chosen so that $75 \%, 50 \%, 25 \%$, and $5 \%$ of the wavelet power is above each level, respectively. Black contour is the $5 \%$ significance level, using a red noise (autoregressive lag 1) background spectrum (Torrence and Compo 1998).

\section{The global context of the medieval megadroughts}

Each major North American drought of the instrumental record appears as part of a larger global hydroclimatic "footprint" (Herweijer and Seager 2006, manuscript submitted to Int. J. Climatol., hereafter HESE). This footprint exhibits a clear hemispherically and, in the extratropics, zonally symmetric pattern, in which a cooler-than-normal tropical eastern Pacific and tropical troposphere is accompanied by warm and dry conditions in the midlatitudes. Regions of in-phase extratropical drought include western North America, southern South America (Uruguay, southern Brazil, and north and central Argentina), and much of Europe. Tropical land regions (i.e., in particular over tropical South America and the Sahel) are mostly wet during these periods, with the noticeable exception of central East Africa, which is dry. These large-scale relationships between regions of persistent extratropical drought/wetness arise as part of a global response to both interannual and decadal-scale ENSO variability (HESE). With the North American megadroughts of the MCA holding much in common with their modern-day counterparts (barring duration), we envision the existence of a similar global hydroclimatic pattern, essentially forced a. West PDSI: 1000-1470 A.D.
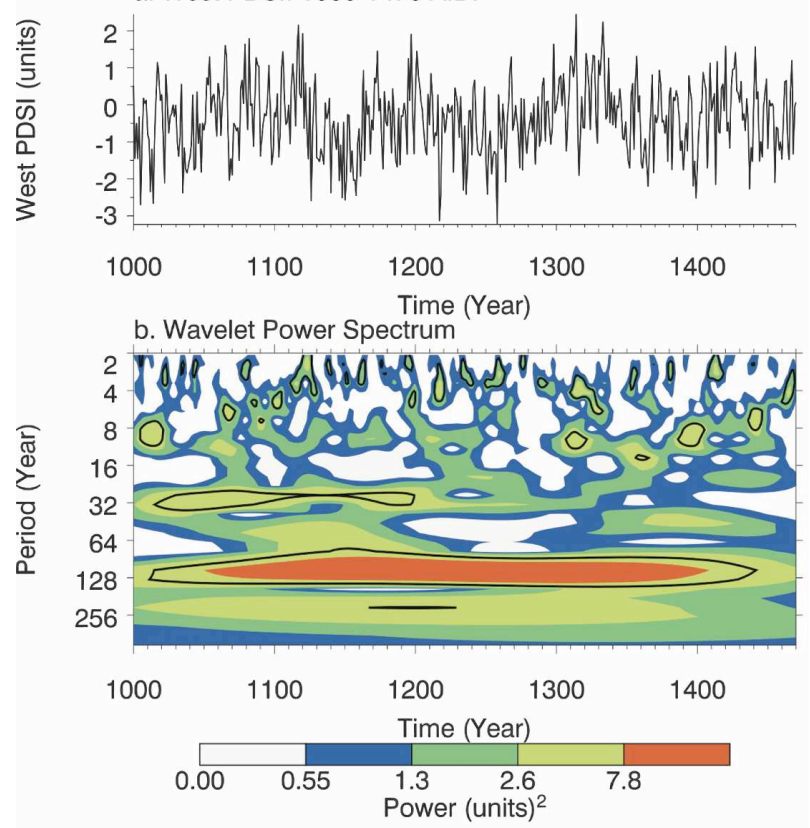

a. West PDSI: 1471-2003 A.D.
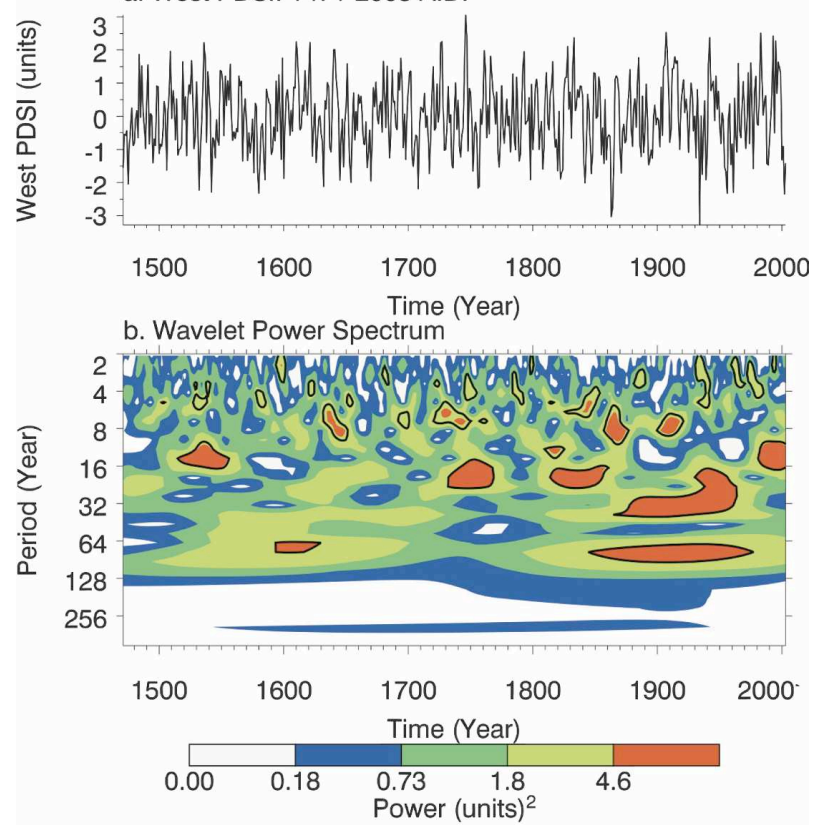

FIG. 12. Same as in Fig. 11, but for the mean West PDSI time series from (top) A.D. 1000 and 1470 and (bottom) A.D. 1470 to 2003.

from a La Niña-like tropical Pacific, which in this case persisted for decades on end. To test this hypothesis, we now turn to examining the existing paleoclimatic evidence in the tropical and extratropical regions of interest.

Figure 13 summarizes the paleo-archived evidence for the medieval ENSO anomalies in the surface ocean 


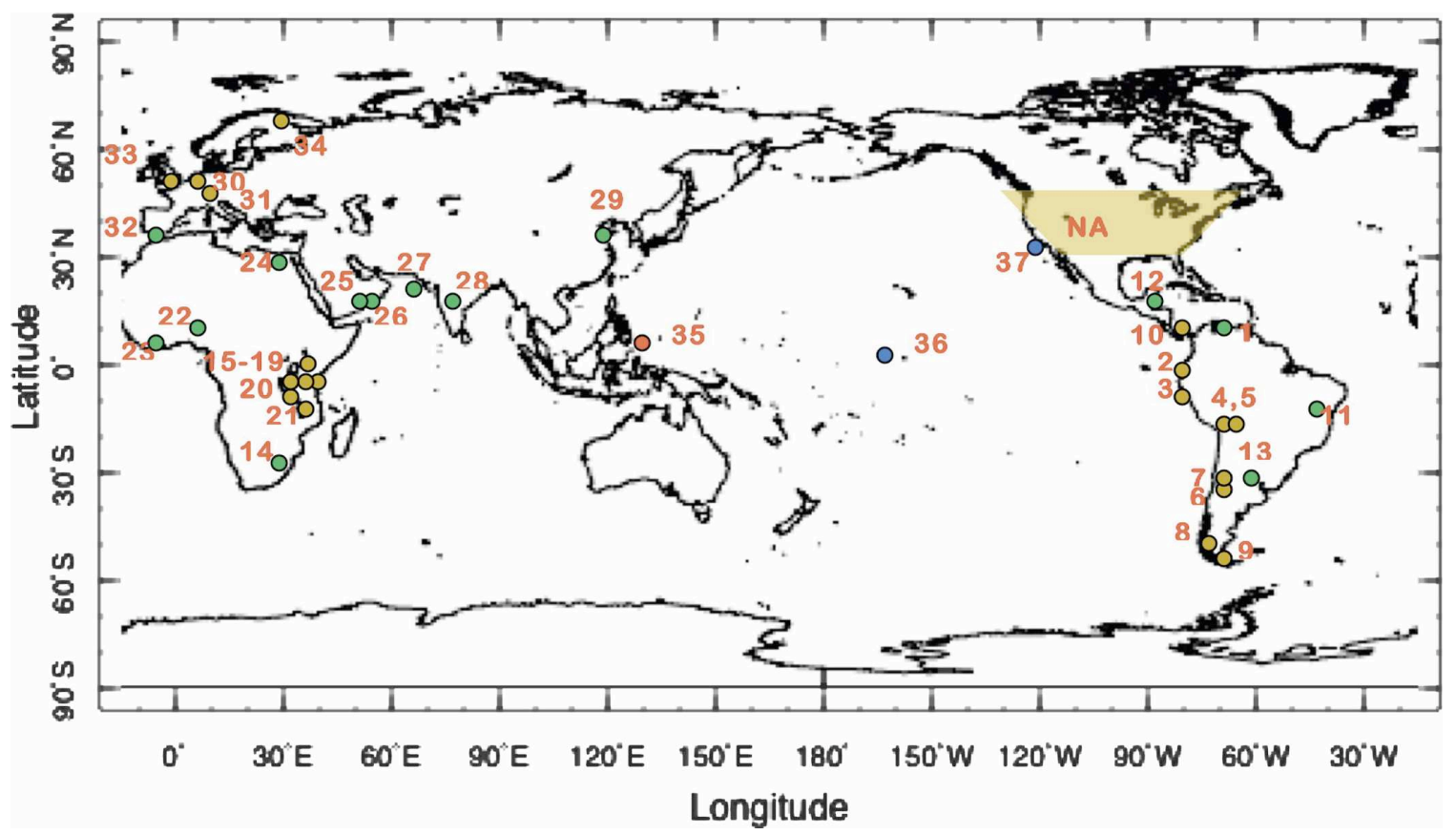

FIG. 13. The global context of the North American medieval megadroughts: map showing the sites of paleo-climatic archives mentioned in the text. Circles represent locations of proxy records giving evidence of wet (green) or dry (brown) conditions. Refer to Table 2 for a description of the numbered archives.

and the hydroclimatic anomalies in ENSO-sensitive tropical and extratropical land regions. Details of the published records represented at each highlighted locality, including the type of paleoarchive, exact location, and the dates discussed, are given in Table 2. In each case we follow the interpretation of the paleorecord provided by the author of the record.

Higher mean $\delta^{18} \mathrm{O}$ values in the twelfth-century fossil coral records from Palmyra Island in the east-central tropical Pacific hint at relatively cool and/or dry mean conditions, consistent with a La Niña-like state (Cobb et al. 2003). An increased zonal temperature gradient across the tropical Pacific is supported by anomalously warm $\mathrm{Mg} / \mathrm{Ca}$ paleotemperatures at the center of the West Pacific Warm Pool peaking between A.D. 900 and 1100 (Stott 2002). In addition, a 5000-yr $\delta^{18} \mathrm{O}$ record from marine plankton in the Santa Barbara basin indicates a period of cooler SSTs and increased upwelling, suggestive of more La Niña-like conditions, from about A.D. 500 to 1300 (Kennett and Kennett 2000). Evidence for La Niña-like conditions is also found in a highresolution marine record off coastal Peru, which shows a period of extreme drought without strong El Niñorelated flooding between A.D. 800 and 1250 (Rein et al. 2004). Consistent with this, sedimentary lake records in the Equadorian Andes (Moy et al. 2002) and the lowlands of Mediterranean central Chile (Jenny et al. 2002), both strongly influenced by ENSO in the mod- ern day, report a minimum of El Niño floods between approximately A.D. 900 and 1200 .

Proxy evidence from Central America and much of tropical South America, both of which tend to be wet during La Niña (Seager et al. 2005a, their Fig. 1), suggest wetter conditions in the Cariaco basin (Haug et al. 2001), the Amazon basin (Colinvaux et al. 1988), and the Yucatan Peninsula (Leyden et al. 1996; Hodell et al. 2001; Hodell et al. 2005). Regarding the latter, the northern Yucatan today lies at a nodal line of the ENSO-precipitation teleconnection pattern during Northern Hemisphere winter (Seager et al. 2005b), and as such we do not anticipate a stable relationship between proxies at this site and ENSO. Contrary to the expected La Niña-like response, a spleotherm record from Lachiniet et al. (2004) suggests that Panama was drier during the MCA. Sediment records from Lake Titicaca point to a lowstand between A.D. 1100 and 1350 (Abbott et al. 1997; Binford et al. 1997), while a snow accumulation record from the Quelccaya ice cap, located $200 \mathrm{~km}$ to the north at the limit of the Lake Titicaca watershed, indicates drier mean conditions from A.D. 1040 to 1490 (Thompson et al. 1985). As for the northern Yucatan sites, this region also lies at a nodal line of the ENSO-precipitation teleconnection pattern, with similar implications for paleo-ENSO interpretation. Farther south, Villalba (1994) show treering evidence for drought in central Chile in the thir- 
teenth century. Again, this evidence is consistent with the modern-day hydroclimatic response to La Niña. However, geomorphological evidence presented by Carignano (1999), Cioccale (1999), and Iriondo (1999) suggests that the MCA in central Argentina was generally wet, a region often in phase with western North America, and dry during La Niña (HESE). Finally, at the southernmost tip of South America, the MCA is recorded in Patagonia as a dry period (Stine and Stine 1990; Stine 1994; Haberzettl et al. 2005) and once again fits the footprint of persistent extratropical droughts in the modern day (HESE).

Across the Atlantic, the MCA is recorded by multiple archives in central East Africa, a region in phase with North American drought in the instrumental era (HESE). Lakes Naivasha, Victoria, Turkana, Edward, Tanganyika, and Malawi all experienced pronounced and prolonged drought during the A.D. $1050-1400$ period (Halfman and Johnson 1988; Owen et al. 1990; Mohammed et al. 1996; Verschuren et al. 2000; Vershcuren 2000; Johnson et al. 2001; Alin and Cohen 2003; Lamb et al. 2001; Russell et al. 2003; Stager et al. 2005). Close by, Mt. Kilimanjaro's oxygen isotope record shows some of its heaviest values during the last $1500 \mathrm{yr}$ in the late eleventh century, again suggesting diminished precipitation in central East Africa (Thompson et al. 2003). A stalagmite record from the Makapansgat valley in the northeastern interior of South Africa is inversely correlated with the East African archives (Holmgren et al. 1999; Tyson et al. 2002), as is the ENSO-induced hydroclimatic variability in the two regions (Allan et al. 1996). In the Sahel, where wet conditions correlate with La Niña, multiproxy palaeolimnological records from northeastern Nigeria (Holmes et al. 1999; Street-Perrot et al. 2005) and Ghana (Talbot and Delibrias 1977) suggest a wet MCA, as do historical sources from the West African Sahel summarized by Nicholson (1996). Farther northeast, the Nilometer records are more characteristic of a La Niña-like response, displaying a consistent lack of E1 Niño-related lowstands between A.D. 1000 and 1290 (Quinn 1993; De Putter et al. 1998).

Low-frequency precipitation variability in much of Europe is also in phase with western North America over the modern period (HESE). Hydroclimatic reconstructions for the MCA (also known as the Middle Ages in Europe) are few and far between in comparison to their paleotemperature counterparts. However, multiproxy evidence for the Kola Peninsula in northeast Russia (Kremenetski et al. 2004), records of Dutch river floods (Tol and Langen 2000), Alexandre's (1987) summer dryness index for central Europe, and Lamb's
(1965) compilation of early European meteorological reports (between about $45^{\circ} \mathrm{N}$ and $55^{\circ} \mathrm{S}$ during the summer season) all point to a period of dry conditions falling somewhere between A.D. 1000 and 1350. Farther south, flood records in the Tagus basin (Benito et al.1996, 2003) and other Atlantic basins of the central/ southern Iberian Peninsula (Benito et al. 1996) suggest wet conditions in the twelfth and thirteenth centuries. In the modern day, both a negative North Atlantic Oscillation (NAO) index and La Niña correlate with wet conditions in this region (Hurrell 1995; Dai et al. 1997; Merkel and Latif 2002; Seager et al. 2005a; Mariotti et al. 2005).

The well-known interaction between ENSO and the south Asian monsoon is such that cold events in the tropical Pacific (i.e., La Niña) go hand-in-hand with a strengthened Asian monsoon (e.g., Rasmusson and Carpenter 1983; Webster and Yang 1992; Ju and Slingo 1995; Webster 1995; Meehl 1997). During the MCA, evidence for an enhanced summer Asian monsoon comes from stalagmites from a shallow cave in southern Oman (Fleitmann et al. 2003), monsoon proxy-records adjacent to the Oman Margin (Gupta et al. 2003) and on the continental slope off Pakistan (Von Rad et al. 1999), a speleotherm $\delta^{18} \mathrm{O}$ record from southwest India (Sinha et al. 2005), and farther east from a fossil pollen series from Maili Bog, in northeast China (Ren 1998). Each of these reconstructions suggests a wetter period indicative of increased summer monsoon rainfall in the period between A.D. 1000 and 1300/1400. Once again, these reconstructions are perfectly accordant with the notion of a La Niña hydroclimatic footprint during medieval times.

In summary, a survey of existing paleoclimatic reconstructions for the MCA largely supports our proposition that the North American medieval megadroughts are part of a global hydroclimatic regime linked to persistent La Niña-like conditions in the tropical Pacific. In general, the hemispheric and zonal symmetry of this pattern is analagous to that observed for the shorter droughts of instrumental times and consistent with the GCM studies (Seager et al. 2005b; Herweijer et al. 2006; HESE). The North American megadroughts are accompanied by dry conditions in southern South America (central Argentina being an exception), central East Africa, and much of Europe, while tropical land regions including the tropical Americas and the African Sahel are wet, as are regions influenced by an intensified south Asian monsoon. The simplest explanation for the medieval hydroclimate is that the tropical Pacific adopted a more La Niña-like state for decades on end during this time. 
TABLE 2. Description of the paleoclimatic archive sites shown in Fig. 13.

\begin{tabular}{|c|c|c|c|c|}
\hline No. & Citation & Location & Archive type & $\begin{array}{l}\text { Date } \\
\text { referenced }\end{array}$ \\
\hline 1 & Haug et al. (2001) & Cariaco basin & $\begin{array}{l}\text { Marine core-bulk Ti, Fe } \\
\text { concentrations }\end{array}$ & A.D. $950-1300$ \\
\hline 2 & Moy et al. (2002) & Ecuadorian Andies & Sedimentary lake record & A.D. $900-1200$ \\
\hline 3 & Rein et al. (2004) & Off coastal Peru & $\begin{array}{l}\text { Marine core-lithic } \\
\text { concentrations }\end{array}$ & A.D. $800-1250$ \\
\hline \multirow[t]{2}{*}{4} & Abbott et al. (1997) & Lake Titicaca & Lake levels & A.D. $1100-1350$ \\
\hline & Binford et al. (1997) & & $\begin{array}{l}\text { Lake stratigraphy, corbonate } \\
\delta^{18} \mathrm{O} \text {, raised field } \\
\text { chronology }\end{array}$ & A.D. $1150-1300$ \\
\hline 5 & Thompson et al. (1985) & Quelccaya ice cap & Snow accumulation & A.D. $1040-1490$ \\
\hline 6 & Villalba (1994) & Central Chile & Tree rings & A.D. $1280-1450$ \\
\hline 7 & Jenny et al. (2002) & Central Chile & Lake sediments-multiproxy & A.D. $950-1300$ \\
\hline \multirow[t]{2}{*}{8} & Stine and Stine (1990) & Lago Cardiel, Patagonia & $\begin{array}{l}\text { Lake lowstands from } \\
\text { shoreline reconstructions }\end{array}$ & A.D. $1150 \pm 110$ \\
\hline & Stine (1994) & Lago Argentino, Patagonia & $\begin{array}{l}\text { Lake lowstands from } \\
\text { submerged stumps }\end{array}$ & A.D. $1160 \pm 115$ \\
\hline 9 & Haberzettl et al. (2005) & Southeast Patagonia & $\begin{array}{l}\text { Total inorganic carbon of lake } \\
\text { sediments }\end{array}$ & A.D. $1230-1410$ \\
\hline 10 & Lachiniet et al. (2004) & Southern Panama & Spleotherm $\delta^{18} \mathrm{O}$ record & A.D. $900-1310$ \\
\hline 11 & Colinvaux et al. (1988) & Amazon basin & Fossil pollen record & A.D. $700-1200$ \\
\hline \multirow[t]{3}{*}{12} & Hodell et al. (2005) & Northwest Yucatan & Lake carbonate $\delta^{18} \mathrm{O}$ record & A.D. $1200-1400$ \\
\hline & Hodell et al. (2001) & North-central Yucatan & Lake carbonate $\delta^{18} \mathrm{O}$ record & A.D. $1100-1350$ \\
\hline & Leyden et al. (1996) & Northwest Yucatan & Lake pollen records & A.D. $1100-1500$ \\
\hline \multirow[t]{3}{*}{13} & Cioccale (1999) & Central Argentina & Geomorphological & A.D. $1100-1400$ \\
\hline & Carignano (1999) & Central Argentina & Geomorphological & A.D. $1000-1400$ \\
\hline & Iriondo (1999) & Central Argentina & Geomorphological & A.D. $600-1200$ \\
\hline \multirow[t]{2}{*}{14} & Tyson et al. (2002) & Northeast South Africa & Stalagmite $\delta^{18} \mathrm{O}$ record & A.D. $900-1320$ \\
\hline & Holmgren et al. (1999) & Northeast South Africa & Stalagmite $\delta^{18} \mathrm{O}$ record & A.D. $900-1320$ \\
\hline \multirow[t]{3}{*}{15} & Mohammed et al. (1996) & Lake Turkana, Kenya & Lake pollen assemblages & A.D. $1100-1400$ \\
\hline & Halfman et al. (1994) & & $\begin{array}{l}\text { Lake levels (carbonate } \\
\text { content and magnetic } \\
\text { susceptibility) }\end{array}$ & A.D. $900-1200$ \\
\hline & Halfman and Johnson (1988) & & $\begin{array}{l}\text { Lake levels (carbonate } \\
\text { content) }\end{array}$ & A.D. $1100-1500$ \\
\hline 16 & $\begin{array}{l}\text { Verschuren et al. (2000) } \\
\text { and Vershuren (2001) }\end{array}$ & Lake Naivasha, Kenya & Sedimentary lake record & A.D. $1000-1270$ \\
\hline 17 & Stager et al. (2005) & Lake Victoria, East Africa & Lake levels and conductivities & $\begin{array}{l}\text { A.D. } 1180-1240 \\
\text { and } 1320-40\end{array}$ \\
\hline 18 & Russell et al. (2003) & Lake Edward, East Africa & Lake levels & A.D. 1100 \\
\hline 19 & Thompson et al. (2003) & Mt. Kilimanjaro, Tanzania & $\delta^{18} \mathrm{O}$ of ice & A.D. $1040-1100$ \\
\hline 20 & Alin and Cohen (2003) & Lake Tanganyika, East Africa & Lake levels (ostrocod based) & A.D. $1050-1250$ \\
\hline \multirow[t]{2}{*}{21} & Johnson et al. (2001) & Lake Malawi, Malawi & $\begin{array}{l}\text { Lake levels (biogenic } \mathrm{Si} \\
\text { abundance) }\end{array}$ & A.D. $1300-1520$ \\
\hline & Owen et al. (1990) & & Lake levels & A.D. $1150-1250$ \\
\hline \multirow[t]{3}{*}{22} & Street-Perrot et al. (2000) & $\begin{array}{l}\text { Manga grasslands, northeast } \\
\text { Nigeria }\end{array}$ & Multiproxy paleolimnological & A.D. 1000 \\
\hline & Holmes et al. (1999) & Bal Lake, northeast Nigeria & Multiproxy paleolimnological & A.D. $1000-1500$ \\
\hline & Nicholson (1996) & West African Sahel & Historical accounts & $800-1200$ \\
\hline 23 & Talbot and Delibrias (1977) & Lake Bosumtwi, Ghana & Lake levels & Until A.D. $1300 \pm 90$ \\
\hline \multirow[t]{2}{*}{24} & De Putter et al. (1998) & Nile, Egypt & Low water level record & A.D. $1100-1200$ \\
\hline & Quinn (1993) & & Nilometer record & A.D. $1000-1290$ \\
\hline 25 & Fleitmann et al. (2003) & Southern Oman & Stalagmite $\delta^{18} \mathrm{O}$ record & $\begin{array}{l}\text { Before A.D. } 1320 \\
\text { (record starts } \\
\text { A.D. 1220) }\end{array}$ \\
\hline 26 & Gupta et al. (2003) & Oman margin, Arabian Sea & $\begin{array}{l}\text { Marine core-\% G. bulloides } \\
\text { and haematite }\end{array}$ & A.D. $800-1400$ \\
\hline 27 & von Rad et al. (1999) & Pakistan margin, Arabian sea & $\begin{array}{l}\text { Marine core-varve thickness } \\
\text { record }\end{array}$ & A.D. $1000-1300$ \\
\hline
\end{tabular}


TABLE 2. (Continued)

\begin{tabular}{|c|c|c|c|c|}
\hline No. & Citation & Location & Archive type & $\begin{array}{l}\text { Date } \\
\text { referenced }\end{array}$ \\
\hline 28 & Sinha et al. (2005) & Dandak Cave, India & Speleotherm $\delta^{18} \mathrm{O}$ record & A.D. $1000-1340$ \\
\hline 29 & Ren (1998) & Maili Bog, northeast China & Fossil pollen record & A.D. $1000-1340$ \\
\hline 30 & Tol and Langen (2000) & $\begin{array}{l}\text { Dutch rivers (Rhine and } \\
\text { Reuse) }\end{array}$ & River flood records & A.D. $1150-1350$ \\
\hline 31 & Alexandre (1987) & Central Europe & Summer dryness index & A.D. $1200-1300$ \\
\hline 32 & Benito et al. $(1996,2003)$ & Central Spain & $\begin{array}{l}\text { Basin water stage record and } \\
\text { flood record }\end{array}$ & A.D. $1150-1300$ \\
\hline 33 & Lamb (1965) & Europe between $45^{\circ}$ and $55^{\circ} \mathrm{N}$ & $\begin{array}{l}\text { Compilation of early } \\
\text { meteorological accounts }\end{array}$ & A.D. $1000-1300$ \\
\hline 34 & Kremenetski et al. (2004) & $\begin{array}{l}\text { Kola Peninsula, northwest } \\
\text { Russia }\end{array}$ & $\begin{array}{l}\text { Lake levels and avalanche } \\
\text { activity }\end{array}$ & A.D. $1000-1200$ \\
\hline 35 & Stott (2002) & $\begin{array}{l}\text { Indonesian Archipelagpo, } \\
\text { west tropical Pacific }\end{array}$ & $\mathrm{Mg} / \mathrm{Ca}$ and $\delta^{18} \mathrm{O}$ of $G$. ruber & $\begin{array}{l}\text { A.D. } 900-1500 \\
\text { (warmest } 900-1100 \text { ) }\end{array}$ \\
\hline 36 & Cobb et al. (2003) & $\begin{array}{l}\text { Palmyra Island, east-central } \\
\text { tropical Pacific }\end{array}$ & Coral $\delta^{18} \mathrm{O}$ record & $\begin{array}{l}\text { A.D. } 928-961 \text { and } \\
\text { A.D. } 1149-1220\end{array}$ \\
\hline 37 & Kennett and Kennett (2000) & Santa Barbara basin & Marine $\delta^{18} \mathrm{O}$ record & A.D. $500-1300$ \\
\hline
\end{tabular}

\section{Conclusions}

The recently available grid of summer PDSI reconstructions developed from a network of drought-sensitive tree-ring chronologies across most of North America provides an invaluable insight into the nature of one of the most costly natural disasters of our times. Many of these reconstructions cover the last $1000 \mathrm{yr}$, enabling us to examine, in detail, how the famous droughts of modern times compare to their predecessors during a time of quite similar boundary conditions (e.g., orbital configuration). Upon examination, what becomes apparent is that the famous droughts of the instrumental era are dwarfed by the successive occurrence of multidecade-long "megadroughts" in the period of elevated aridity between the eleventh and fourteenth centuries A.D. While these megadroughts stand out in terms of persistence, they share the severity and spatial distribution characteristics of their modern-day counterparts. The implication is that the mechanism forcing persistent droughts in the West and Plains in the current climate is synonymous with that underlying the megadroughts of the medieval period. The difference is the persistence of this forcing.

Three distinct spatial modes of North American drought variability are revealed by rotated principal component analysis of the gridded PDSI reconstructions. The first resembles the North American ENSO pattern: widespread drought across the United States with centers in the Southwest and a hint of the opposite sign in the Pacific Northwest and the Northeast. Correlation with instrumental SSTA and SLPA data confirms the link to ENSO-like variability. The second and third rotated factors represent largely monopolar structures with drought centers in the Plains/Mississippi Val- ley and Northwest regions, respectively. The second mode may be weakly related to the North Atlantic Oscillation. As expected, the identified drought centers all coincide with regions of maximum PDSI variance. The first (Southwest center) and second (Plains/Mississippi Valley center) leading modes are located in the continental Interior region dominated by low-frequency variability, while the third (Northwest center) mode lies in a region in which interannual ENSO-scale PDSI variability dominates. Importantly, the physical reality of all three spatial modes is reflected by their occurrence in the untreated drought reconstructions.

Both the MTM and wavelet analsysis of the PDSI variability in the West reveal consistent findings: 1) interannual ENSO variability exists and is prominent throughout the last millennium; 2) centennial variability dominates in the arid medieval period; and 3) bidecadal variability is significant only in the latter half of the millennium. We make no inference as to the cause of the centennial and bidecadal signals, frequencies that in the past have been linked to solar (centennial and bidecadal) and lunar (bidecadal) cycles. However, future research in this area is clearly warranted.

The exceptional persistence of the North American medieval megadroughts requires an explanation. Climate model simulations of the recent period indicate that La Niña-like SSTs in the tropical Pacific play a large role in forcing the major North American droughts since 1850. With ENSO clearly a key player in the gridded drought reconstructions of the last millennium, both in terms of its link to the leading spatial mode and leading time scales of drought variability, it seems a logical next step to relate the occurrence of medieval megadroughts to protracted cool La Niñalike SSTs in the tropical Pacific. In the modern day, 
each of the widespread multiyear North American droughts fits into a global pattern, whereby a cool tropical Pacific is accompanied by hemispheric, and in the extratropics, zonally symmetric patterns of precipitation anomalies. By extension, a tropical Pacific origin for the medieval megadroughts would warrant a similar "global footprint." Examination of the paleoclimatic record gives much support to the notion that La Niñalike conditions characterized the MCA. Archives from the tropical Pacific surface ocean, to tropical and extratropical land regions sensitive to ENSO in the modern day, exhibit a response largely akin to the modern-day global hydroclimatic footprint of persistent La Niñalike conditions.

The occurrence of La Niña-like SSTs in the tropical Pacific of medieval times coincides with a period of presumed greater solar irradiance and reduced volcanism than in subsequent centuries (Mann et al. 2005). Mann et al. (2005) invoked the Bjerknes (1969) feedback to explain how increased irradiance and reduced volcanism can induce a La Niña-like state in the Pacific. The Bjerknes feedback mechanism has been used to explain this link whereby increased irradiance leads to the development of cool La Niña-like SSTs in the eastern tropical Pacific. Cane et al. (1997) have suggested that rising greenhouse gases could also induce a $\mathrm{La}$ Niña-like state, although climate model experiments tend to give mixed results in this regard. Nevertheless, the medieval conjunction of increased radiative forcing, a La Niña-like tropical Pacific, and North American megadrought is cautionary. Furthermore, anthropogenic climate change aside, the 1000-yr-long gridded reconstruction of North American droughts presents unequivocal evidence that the natural range of North American drought variability in the late Holocene includes the occurrence of successive megadroughts, similar in severity to the famous droughts of modern times, yet exceptional in sheer duration. In medieval times, the human impact of such megadroughts may have been a contributing factor to the Puebloan migrations from the Four Corners region (i.e., Jones et al. 1990; Axtell et al. 2002) and the abandonment of Mississippian chiefdoms to the east (Cook et al. 2007), but how would modern-day Western society react? The prospect of megadrought in the west is much more daunting now than during the times of the Puebloans, as the affected population is far greater-over 100 million in the western United States and Mexico. Undoubtably today's water-thirsty west, with its collossal urban and agricultural infrastructure dependent on the assumption that runoff will continue as it has done since the draining of Owens Valley in the 1920s, would be pummeled by a megadrought of medieval scale. How the west, and other worldwide regions of in-phase drought, would fare is yet to be tested.

Acknowledgments. We are very grateful to Yochanan Kushnir, Connie Woodhouse, and Mark Cane for useful discussions of this work. Thanks also to the useful and thought-provoking comments from the anonymous reviewers. $\mathrm{CH}$ was supported by NASA Grant NNG04GQ55H. RS was supported by NOAA Grants NAO30AR4320179 P07 and 20A and an NSF Earth System History grant. ERC and JE-G were supported by NOAA Grant NAO30AR4320179 P07. The North American Drought Atlas data of Cook and Krusic (2004) can be downloaded and seen online (http:// www.ncdc.noaa.gov/paleo/newpdsi.html and http:// iridl.ldeo.columbia.edu/expert/home/.benno/.LDEO/. TRL/.NADA2004/.psdi/).

\section{REFERENCES}

Abbott, M. B., M. W. Binford, M. Brenner, and K. R. Kelts, 1997: A $350014 \mathrm{C}$ yr high-resolution record of water-level changes in Lake Titicaca, Bolivia/Peru. Quat. Res., 47, 169-180.

Alexandre, P., 1987: Le Climat en Europe au Moyen Age: Contribution à l'Histoire des Variations Climatiques de 1000 à 1425 d'après les Sources Narratives de l'Europe Occidentale. Ecole des Hautes Etudes en Sciences Sociales, 827 pp.

Alin, S. R., and A. S. Cohen, 2003: Lake-level history of Lake Tanganyika, East Africa, for the past 2500 years based on ostracode-inferred water-depth reconstruction. Paleogeogr. Paleoclimatol. Paleoecol., 199, 31-49.

Allan, R. A., J. A. Lindesay, and D. Parker, 1996: El Nino, Southern Oscillation and Climatic Variability. CSIRO, 416 pp.

Atlas, R., N. Wolfson, and J. Terry, 1993: The effect of SST and soil moisture anomalies on GLA model simulations of the 1988 U.S. summer drought. J. Climate, 6, 2034-2047.

Axtell, R. L., and Coauthors, 2002: Population growth and collapse in a multiagent model of the Kayenta Anasazi in Long House Valley. Proc. Natl. Acad. Sci. USA, 99 (Suppl. 3), 7275-7279.

Bard, E., G. Raisbeck, F. Yiou, and J. Jouzel, 2001: Solar irradiance during the last 1200 years based on cosmogenic nuclides. Tellus, 52B, 985-992.

Benito, G., M. J. Machado, and A. Perez-Gonzalez, 1996: Climate change and flood sensitivity in Spain? Global Continental Changes: The Context of Palaeohydrology, J. Branson, A. G. Brown, and K. J. Gregory, Eds., Special Publication 115, Geological Society, 85-98.

_ A. Díez-Herrero, and M. Fernández de Villalta, 2003: Magnitude and frequency of flooding in the Tagus Basin (central Spain) over the last millenium. Climate Change, 58, 171-192.

Berger, A. L., J. L. Melice, and L. Hinnov, 1991: A strategy for frequency spectra of Quaternary climate records. Climate Dyn., 5, 227-240.

Binford, M. A., M. Kolata, M. Brenner, L. Janusek, M. Seddon, M. Abbott, and J. Curtis, 1997: Climate variation and the rise and fall of an Andean civilization. Quat. Res., 47, 235-248.

Bjerknes, J., 1969: Atmospheric teleconnections from the equatorial Pacific. Mon. Wea. Rev., 97, 163-172. 
Bradley, R. S., M. K. Hughes, and H. F. Diaz, 2003: Climate in medieval time. Science, 302, 404-405.

Cane, M. A., A. C. Clement, A. Kaplan, Y. Kushnir, R. Murtugudde, D. Pozdnyakov, R. Seager, and S. E. Zebiak, 1997: 20th century sea surface temperature trends. Science, 275, 957-960.

Carignano, C. R., 1999: Late Pleistocene to recent climatic chance in Cordoba Province, Argentina: Geomorphological evidence. Quat. Int., 57/58, 117-134.

Cioccale, M. A., 1999: Climatic fluctuations in the Central Region of Argentina in the last 1000 years. Quat. Int., 62, 35-47.

Clegg, S. L., and T. M. L. Wigely, 1984: Periodicities in precipitation in north-east China, 1470-1979. Geophys. Res. Lett., 11, 1219-1222.

Clement, A., R. Seager, M. A. Cane, and S. E. Zebiak, 1996: An ocean dynamical thermostat. J. Climate, 9, 2190-2196.

Cobb, K. M., C. D. Charles, H. Cheng, and R. L. Edwards, 2003: El Nino/Southern Oscillation and tropical Pacific climate change during the last millenium. Nature, 424, 271-276.

Cole, J. E., J. T. Overpeck, and E. R. Cook, 2002: Multiyear La Niña events and persistent drought in the contiguous United States. Geophys. Res. Lett., 29, 1647, doi:10.1029/ 2001 GL013561.

Colinvaux, P. A., M. Frost, I. Frost, K.-B. Liu, and M. SteinitzKannan, 1988: Three pollen diagrams of forest distrubance in the western Amazon Basin. Rev. Palaeobot. Palynol., 55, 7381.

Cook, E. R., and P. J. Krusic, 2004: North American summer PDSI reconstructions. IGBP PAGES/World Data Center for Paleoclimatology Data Contribution Series No. 2004-045, NOAA/NGDC Paleoclimatology Program, Boulder, CO, 24 pp.

, D. M. Meko, and C. W. Stockton, 1997: A new assessment of possible solar and lunar forcing of the bidecadal drought rhythm in the western United States. J. Climate, 10, 13431356.

-, D. W. Stahle, and M. K. Cleaveland, 1999: Drought recontructions for the continental United States. J. Climate, 12, 1145-1162.

—, C. A. Woodhouse, C. M. Eakin, D. M. Meko, and D. W. Stahle, 2004: Long term aridity changes in the western United States. Science, 306, 1015-1018.

—, R. Seager, M. A. Cane, and D. W. Stahle, 2007: North American drought: Reconstructions, causes and consequences. Earth-Sci. Rev., in press.

Crowley, T. J., 2000: Causes of climate change over the past 1000 years. Science, 289, 270-277.

Currie, R. G., 1981: Evidence for 18.6 year MN signal in temperature and drought conditions in North America since A.D. 1800. J. Geophys. Res., 86, 11 055-11 064.

_ 1984a: Evidence for 18.6-year lunar nodal drought in western North America during the past millennium. J. Geophys. Res., 89, 1295-1308.

_ $1984 \mathrm{~b}$ : Periodic (18.6-year) and cyclic (11-year) induced drought and flood in western North America. J. Geophys. Res., 89, 7215-7230.

Dai, A., I. Y. Fung, and A. D. Del Genio, 1997: Surface observed global land precipitation variations during 1900-88. J. Climate, 10, 2943-2962.

- K. E. Trenberth, and T. Qian, 2004: A global dataset of Palmer Drought Severity Index for 1870-2002: Relationship with soil moisture and effects of surface warming. J. Hydrometeor., 5, 1117-1130.
Dean, W. E., 1997: Rates, timing, and cyclicity of Holocene eolian activity in north-central United States: Evidence from varved lake sediments. Geology, 25, 331-334.

De Putter, T., M.-F. Loutre, and G. Wansard, 1998: Decadal periodicities of Nile River historical discharge (A.D. 622-1470) and climatic implications. Geophys. Res. Lett., 25, 3193-3196.

Emile-Geay, J. E., R. Seager, M. A. Cane, and E. R. Cook, 2007: The 1258 volcanic eruption and the subsequent ENSO event. Geophys. Res. Lett., in press.

FEMA, 1995: National mitigation strategy: Partnerships for building safer communities. Mitigation Directorate, Federal Emergency Management Agency.

Fleitmann, D., S. J. Burns, M. Mudelsee, U. Neff, J. Kramers, A. Mangini, and A. Matter, 2003: Holocene forcing of the Indian monsoon recorded in a stalagmite from southern Oman. Science, 300, 1737-1739.

Forman, S. L., R. Oglesby, V. Markgraf, and T. Stafford, 1995: Paleoclimatic significance of late Quaternary eolian deposition on the Piedmont and High Plains, central United States. Global Planet. Change, 11, 35-55.

$\_,-$, and S. Webb, 2001: Temporal and spatial patterns of Holocene dune activity on the Great Plains of North America: Megadroughts and climate links. Global Planet. Change, 29 (1-2), 1-29.

Fritz, S. C., E. Ito, Z. Yu, K. R. Laird, and D. R. Engstrom, 2000: Hydrologic variation in the Northern Great Plains during the last two millenia. Quart. Res., 53, 175-184.

Fye, F. K., D. W. Stahle, and E. R. Cook, 2003: Paleoclimate analogs to twentieth-century moisture regimes across the United States. Bull. Amer. Meteor. Soc., 84, 901-909.

Ghil, M., and Coauthors, 2001: Advanced spectral methods for climatic timeseries. Rev. Geophys., 40, 1-41.

Gray, S. T., J. L. Betancourt, C. L. Fastie, and S. T. Jackson, 2003: Patterns and sources of multidecadal oscillations in droughtsensitive tree-ring records from the central and southern Rocky Mountains. Geophys. Res. Lett., 30, 49-1-49-4.

Gupta, A. K., D. M. Anderson, and J. T. Overpeck, 2003: Abrupt changes in the Asian southwest monsoon during the Holocene and their links to the North Atlantic Ocean. Nature, 412, 354-357.

Haberzettl, T., and Coauthors, 2005: Climatically induced lake level changes during the last two millennia as reflected in sediments of Laguna Potrok Aike, southern Patagonia (Santa Cruz, Argentina). J. Paleolimnol., 33, 283-302.

Halfman, J. D., and T. C. Johnson, 1988: High resolution record of cyclic climatic change during the past $4 \mathrm{ka}$ from Lake Turkana, Kenya. Geology, 16, 496-500.

,$- \ldots$, and B. P. Finney, 1994: New AMS dates, stratigraphic correlations and decadal climatic cycles for the past $4 \mathrm{ka}$ at Lake Turkana, Kenya. Palaeogeogr. Palaeoclimatol. Palaeoecol., 111, 83-98.

Hameed, S., W. M. Yeh, M. T. Li, R. D. Cess, and W. C. Wang, 1983: An analysis of periodicities in the 1470 to 1974 Beijing precipitation record. Geophys. Res. Lett., 10, 436-439.

Haug, G. H., K. A. Hughen, D. M. Sigman, L. C. Peterson, and U. Rohl, 2001: Southward migration of the Intertropical Convergence Zone through the Holocene. Science, 293, 1304 1308.

Hazeleger, W., R. Seager, M. A. Cane, and N. H. Naik, 2004: How can tropical Pacific Ocean heat transport vary? J. Phys. Oceanog., 34, 320-333.

Heim, R. R., Jr., 2002: A review of twentieth-century drought 
indices used in the UnitedStates. Bull. Amer. Meteor. Soc., 83, 1149-1165.

Herweijer, C., R. Seager, and E. R. Cook, 2006: North American droughts of the mid-to-late nineteenth century: A history, simulation and implication for Medieval drought. Holocene, 16, 159-171.

Hodell, D. A., M. Brenner, J. H. Curtis, and T. Guilderson, 2001: Solar forcing of drought frequency in the Maya lowlands. Science, 202, 1367-1370.

,,,--- R. Medina-Gonzalez, E. Ildefonso-Chan Can, A. Albornaz-Pat, and T. P. Guilderson, 2005: Climate change on the Yucatan Peninsula during the Little Ice Age. Quat. Res., 63, 109-121.

Hoerling, M. P., and A. Kumar, 2003: The perfect ocean for drought. Science, 299, 691-699.

Holmes, J. A., M. Allen, F. A. Street-Perrott, and R. A. Perrott, 1999: Palaeolimnology of Bal Lake, Northern Nigeria, over the last millennium based on the faunal ecology and traceelement chemistry of ostracod shells. Palaeogeogr. Palaeoclimatol. Palaeoecol., 148, 169-185.

Holmgren, K., W. Karlén, O. Svanered, S. E. Lauritzen, J. A. LeeThorpt, T. C. Partridge, S. Piketh, and P. D. Tyson, 1999: A 3000-year high-resolution stalagmite based record of palaeoclimate for North-Eastern South Africa. Holocene, 9, 295309.

$\mathrm{Hu}$, Q., and S. Feng, 2001: A southward migration of centennialscale variations of drought/flood in eastern China and the western United States. J. Climate, 14, 1323-1328.

Huang, H.-R., R. Seager, and Y. Kushnir, 2005: The 1976/77 transition in precipitation over the Americas and the influence of tropical sea surface temperature. Climate Dyn., 24, 721-740.

Hurrell, J. W., 1995: Decadal trends in the North Atlantic Oscillation: Regional temperatures and precipitation. Science, 269, 676-679.

Iriondo, M., 1999: Climatic changes in the South American plains: Records of a continent-scale oscillation. Quat. Int., 57/58, 93112.

Jenny, B., B. L. Valero-Garces, R. Urrutia, K. Kelts, H. Veit, P. G. Appleby, and M. Geyh, 2002: Moisture changes and fluctuations of the Westerlies in Mediterranean Central Chile during the last 2000 years: The Laguna Aculeo record (3350'S). Quat. Res., 87, 3-18.

Johnson, T. C., S. L. Barry, Y. Chan, and P. Wilkinson, 2001: Decadal record of climate variability spanning the past $700 \mathrm{yr}$ in the Southern Tropics of East Africa. Geology, 29, 83-86.

Jones, T. L., G. M. Brown, M. L. Raab, J. L. McVickar, W. G. Spalding, J. K. A. York, and P. L. Walker, 1990: Environmental imperatives reconstructed: Demographic crises in Western North America during the Medieval Climatic Anomaly. Curr. Anthro., 40, 137-170.

Ju, J., and J. Slingo, 1995: The Asian summer monsoon and ENSO. Quart. J. Roy. Meteor. Soc., 121, 1133-1168.

Kaiser, H. F., 1960: The application of electronic computers to factor analysis. Educ. Psychol. Measure., 20, 141-151.

Kaplan, A., Y. Kushnir, and M. A. Cane, 2000: Reduced space optimal interpolation of historical marine sea level pressure: 1854-1992. J. Climate, 13, 2987-3002.

_ - M. A. Cane, and Y. Kushnir, 2003: Reduced space approach to the optimal analysis interpolation of historical marine observations: Accomplishments, difficulties, and prospects. Advances in the Applications of Marine Climatology: The Dynamic Part of the WMO Guide to the Applications of Marine
Climatology, WMO/TD-1081, World Meteorological Organization, Geneva, Switzerland, 199-216.

Karl, T. R., and A. J. Koscielny, 1982: Drought in the United States. J. Climatol., 2, 313-329.

Kennett, D. J., and J. P. Kennett, 2000: Competitive and cooperative responses to climatic instability in coastal southern California. Amer. Antiq., 65, 379-395.

Kremenetski, K. V., T. Boettger, G. M. MacDonald, T. Vaschalova, L. Sulerzhitsky, and A. Hiller, 2004: Medieval climate warming and aridity as indicated by multiproxy evidence from the Kola Peninsula, Russia. Palaeogeogr. Palaeoclimatol. Palaeoecol., 209, 113-125.

Lachiniet, M., S. J. Burns, D. R. Piperno, Y. Asmeron, V. J. Polak, C. M. Moy, and K. Christenson, 2004: A 1500-year El Niño/Southern Oscillation and rainfall history from the Isthmus of Panama from spleotherm calcite. J. Geophys. Res., 109, D20117, doi:10.1029/2004JD004694.

Laird, K. R., S. C. Fritz, E. C. Grimm, and P. G. Mueller, 1996: Centuryscale paleoclimatic reconstruction from Moon Lake, a closed-basin lake in the northern Great Plains. Limnol. Oceanogr., 41, 890-902.

$\longrightarrow,-$, and B. F. Cumming, 1998: A diatom-based reconstruction of drought intensity, duration, and frequency from Moon Lake, North Dakota: A sub-decadal record of the last 2300 years. J. Paleolimnol., 19, 161-179.

Lall, U., and M. Mann, 1995: The Great Salt Lake: A barometer of low-frequency climatic variability. Water. Resour. Res., 31, 2503-2515.

Lamb, H. F., 1965: The early Medieval warm epoch and its sequel. Palaeogeogr. Palaeoclimatol. Palaeoecol., 1, 13-37.

— I. I Darbyshire, and D. Verschuren, 2001: Vegetation response to rainfall variation and human impact in central Kenya during the past 1100 years. Holocene, 13, 285-292.

Lau, N.-C., A. Leetmaa, and M. J. Nath, 2006: Attribution of atmospheric variations in the 1997-2003 period to SST anomalies in the Pacific and Indian Ocean basins. J. Climate, 19, 3607-3628.

Lean, J., J. Beer, and R. Bradley, 1995: Reconstruction of solar irradiance since 1610: Implications for climate change. Geophys. Res. Lett., 22, 3195-3198.

Leyden, B. W., M. Brenner, T. Whitmore, J. H. Curtis, D. R. Piperno, and B. H. Dahlin, 1996: A record of long- and shortterm climatic variation from northwest Yucatan: Cenote San Jose Chulchaca. The Managed Mosaic: Ancient Maya Agriculture and Resource Use, S. L. Fedick, Ed., University of Utah Press, 30-50.

Lohmann, G., N. Rimbu, and M. Dima, 2004: Climate signature of solar irradiance variations: Analysis of long-term instrumental, historical, and proxy data. Int. J. Climatol., 24, 1045-1056.

Mann, M. E., and J. Park, 1993: Spatial correlations of interdecadal variation in global surface temperatures. Geophys. Res. Lett., 20, 1055-1058.

_ , and J. M. Lees, 1996: Robust estimation of background noise and signal detection in climatic time series. Climate Change, 33, 409-445.

_ U. Lall, and B. Saltzman, 1995a: Decadal-to-centennialscale climate variability: Insights into the rise and fall of the Great Salt Lake. Geophys. Res. Lett., 22, 937-940.

, J. Park, and R. S. Bradley, 1995b: Global interdecadal and century-scale climate oscillations during the past five centuries. Nature, 378, 266-270.

-, M. A. Cane, S. E. Zebiak, and A. Clement, 2005: Volcanic 
and solar forcing of El Niño over the past 1000 years. $J$. Climate, 18, 447-456.

Mariotti, A., J. Ballabrera-Poy, and N. Zeng, 2005: Tropical influence on Euro-Asian autumn rainfall variability. Climate Dyn., 24, 511-521.

Meehl, G. A., 1997: The South Asian monsoon and the tropospheric biennial oscillation. J. Climate, 10, 1921-1943.

Merkel, U., and M. Latif, 2002: A high-resolution AGCM study of the E1 Niño impact on the North Atlantic/European sector. Geophys. Res. Lett., 29, 1291, doi:10.1029/2001GL013726.

Mitchell, J. M., Jr., C. W. Stockton, and D. M. Meko, 1979: Evidence of a 22-year rhythm of drought in the western United States related to the Hale solar cycle since the 17th century. Solar Terrestrial Influences on Weather and Climate, B. M. McCormac and T. A. Seliga, Eds., D. Reidel, 125-144.

Mo, K. C., J. R. Zimmerman, E. Kalnay, and M. Kanamitsu, 1991: A GCM study of the 1988 United States drought. Mon. Wea. Rev., 119, 1512-1532.

Mohammed, M. U., R. Bonnefille, and T. C. Johnson, 1996: Pollen and isotopic records in Late Holocene sediments from Lake Turkana, Kenya. Palaeogeogr. Palaeoclimatol. Palaeoecol., 119, 371-383.

Mommersteeg, H., M. F. Loutre, R. Young, T. A. Wijmstra, and H. Hooghiemstra, 1995: Orbital forced frequencies in the 975000 year pollen record from Tenagi Philippon (Greece). Climate Dyn., 11, 4-24.

Moy, C. M., G. O. Seltzer, D. T. Rodbell, and D. M. Anderson, 2002: Variability of El Niño/Southern Oscillation activity at millennial timescales during the Holocene epoch. Nature, 420, 162-165.

Muhs, D. R., T. W. Stafford, S. D. Cowherd, S. A. Mahan, R. Kihl, P. B. Maat, C. A. Bush, and J. Nehring, 1996: Origin of the late Quaternary dune fields of northeastern Colorado. Geomorphology, 17, 129-149.

Nicholson, S. E., 1996: Environmental change within the historical period. The Physical Geography of Africa, W. M. Adams, A. S. Goudie, and A. R. Orme, Eds., Oxford University Press, 60-87.

North, G. R., T. L. Bell, R. F. Cahalan, and F. J. Moeng, 1982: Sample errors in the estimation of empirical orthogonal functions. Mon. Wea. Rev., 110, 699-707.

Oppenheimer, C., 2003: Ice core and paleoclimatic evidence of the nature of the great mid-13th century volcanic eruption. Int. J. Climatol., 23, 417-426.

Owen, R. B., R. Crossley, T. C. Johnson, D. Tweddle, I. Kornfield, S. Davidson, D. H. Eccles, and D. E. Engstrom, 1990: Major low levels of Lake Malawi and implications for speciation rates in cichlid fishes. Proc. Roy. Soc. London, 240B, 519-553.

Palmer, W. C., 1965: Meteorological drought. U.S. Department of Commerce, Weather Bureau Research Paper 45, 58 pp.

Park, J., and K. A. Maasch, 1993: Plio-Pleistocene time evolution of the 100-kyr cycle in marine paleoclimate records. J. Geophys. Res., 98, 447-461.

— C. R. Lindberg, and F. L. I. Vernon, 1987: Multitaper spectral analysis of high-frequency seismograms. J. Geophys. Res., 92, 12 675-12 684.

Preisendorfer, R. W., 1988: Principal Component Analysis in Meteorology and Oceanography. Elsevier, $425 \mathrm{pp}$.

Quinn, W. H., 1993: The large-scale ENSO event, the El Niño and other important regional features. Bull. Inst. Fr. Etudes Andines, 22 (1), 13-34.

Rasmusson, E. M., and T. H. Carpenter, 1983: The relationship between eastern equatorial Pacific sea surface temperatures and rainfall over India and Sri Lanka. Mon. Wea. Rev., 111, 517-528.

Rein, B., A. Lückge, and F. Sirocko, 2004: A major Holocene ENSO anomaly during the Medieval period. Geophys. Res. Lett., 31, L17211, doi:10.1029/2004GL020161.

Ren, G., 1998: Pollen evidence for increased summer rainfall in the Medieval warm period at Maili, Northeast China. Geophys. Res. Lett., 25, 1931-1934.

Ross, T., and N. Lott, cited 2003: A climatology of 1980-2003 extreme weather and climate events. National Climatic Data Center Tech. Rep. 2003-01, NOAA/NESDIS, National Climatic Data Center, Asheville, NC. [Available online at http:// www.ncdc.noaa.gov/ol/reports/billionz.html.]

Russell, J. M., T. C. Johnson, and M. R. Talbot, 2003: A 725 yr cycle in the climate of Central Africa during the late Holocene. Geology, 31, 677-680.

Schubert, S. D., M. J. Suarez, P. J. Region, R. D. Koster, and J. T. Bacmeister, 2004: Causes of long-term drought in the United States Great Plains. J. Climate, 17, 485-503.

Seager, R., N. Harnik, W. A. Robinson, Y. Kushnir, M. Ting, and J. V. H. P. Huang, 2005a: Mechanisms of ENSO-forcing of hemispherically symmetric precipitation variability. Quart. J. Roy. Meteor. Soc., 131, 1501-1527.

-, Y. Kushnir, C. Herweijer, N. Naik, and J. Miller, 2005b: Modeling of tropical forcing of persistent droughts and pluvials over western North America: 1856-2000. J. Climate, 18, 4068-4091.

Sinha, A., K. Cannaraito, L. Stott, H. Cheng, and L. Edwards, 2005: Possible solar forcing of late Holocene Indian monsoon rainfall. Eos, Trans. Amer. Geophys. Union, 86 (Fall Meeting Suppl.), Abstract PP41C-06.

Stager, J. C., D. Ryves, B. F. Cumming, L. D. Meeker, and J. Beer, 2005: Solar variability and the levels of Lake Victoria, East Africa, during the last millenium. J. Paleolimnol., 33, 243-251.

Stahle, D. W., E. R. Cook, M. K. Cleavland, M. D. Therrell, D. M. Meko, H. D. Grissino-Mayer, E. Watson, and B. H. Luckman, 2000: Tree-ring data document 16th century megadrought over North America. Eos, Trans. Amer. Geophys. Union, 81, 121-125.

- M. D. Therrell, M. K. Cleaveland, F. K. Fye, E. R. Cook, H. D. Grissino-Mayer, and R. Acuna-Soto, 2002: The 8th century megadrought across North America. Eos, Trans. Amer. Geophys. Union, 83 (Fall Meeting Suppl.), F913-F914.

Stine, S., 1994: Extreme and persistent drought in California and Patagonia in medieval time. Nature, 369, 546-549.

-, and M. Stine, 1990: A record from Lake Cardiel of climate change in southern South America. Nature, 345, 705-708.

Stockton, C. W., J. M. Mitchell Jr., and D. M. Meko, 1983: A reappraisal of the 22-year drought cycle. Solar-Terrestrial Influences on Weather and Climate, B. M. McCormac, Ed., Colorado Associated University Press, 507-515.

Stothers, R. B., 2000: Climatic and demographic consequences of the massive volcanic eruption of 1258. Climate Change, 45, 361-374.

Stott, L. D., 2002: SST variability in the Western Pacific Warm Pool during the past 2000 years. Eos, Trans. Amer. Geophys. Union, 83 (Fall Meeting Suppl.), Abstract PP71C-10.

Street-Perrot, F. A., and Coauthors, 2000: Drought and dust deposition in the west African Sahel: A 5500-year record from Kakemarum Oasis, northeastern Nigeria. Holocene, 10, 293 302. 
Sud, Y. C., D. M. Mocko, K. Lau, and R. Atlas, 2003: Simulating the midwesten U.S. drought of 1988 with a GCM. J. Climate, 16, 3946-3965.

Sutton, R. T., and D. L. R. Hodson, 2005: Atlantic Ocean forcing of North American and European summer climate. Science, 309, 115-118.

Swetnam, T. W., 1993: Fire history and climate change in giant sequoia groves. Science, 262, 885-889.

Talbot, M. R., and G. Delibrias, 1977: Holocene variations in the level of Lake Bosumtwi, Ghana. Nature, 268, 722-724.

Thompson, L. G., E. Mosley-Thompson, J. F. Bolzan, and B. R. Koci 1985: A 1,500-year record of tropical precipitation in ice cores from the Quelccaya ice cap Peru. Science, 229, 971-973.

- - - M. E. Davis, P.-N. Lin, K. Henderson, and T. A. Mashiotta, 2003: Tropical glacier and ice core evidence of climate change on annual to millennial time scales. Climate Change, 59, 137-155.

Tol, R. S. J., and A. Langen, 2000: A concise history of Dutch river floods. Climate Change, 46, 357-369.

Torrence, C., and G. P. Compo, 1998: A practical guide to wavelet analysis. Bull. Amer. Meteor. Soc., 79, 61-78.

Trenberth, K., and G. W. Branstator, 1992: Issues in establishing causes of the 1988 drought over North America. J. Climate, 5, $159-172$.

— , and C. J. Guillemot, 1996: Physical processes involved in the 1988 drought and 1993 floods in North America. J. Climate, 9, 1288-1298.

— , G. W. Branstator, and P. A. Arkin, 1988: Origins of the 1988 North American drought. Science, 242, 1640-1645.

Tyson, P. D., G. R. J. Cooper, and T. S. McCarthy, 2002: Changing gradients of climate change in southern Africa during the past millennium: Implications for population movements. Climate Change, 52, 129-135.

Verschuren, D., 2001: Reconstructing fluctuations of a shallow
East African lake during the past 1800 yrs from sediment stratigraphy in a submerged crater basin. J. Paleolimnol., 25, 297-311.

— K. K. Laird, and B. F. Cumming, 2000: Rainfall and drought in equatorial East Africa during the past 1,100 years. Nature, 403, 410-414.

Villalba, R., 1994: Tree-ring and glacial evidence for the medieval warm epoch and the little ice age in southern South America. Climate Change, 26, 183-189.

von Rad, U., M. Schaaf, K. Michels, H. Schulz, W. Berger, and F. Sirocko, 1999: A 5000-yr record of climate change in varved sediments from the oxygen minimum zone off Pakistan, northeastern Arabian Sea. Quat. Res., 51, 39-53.

Webster, P. J., 1995: The annual cycle and the predictability of the tropical coupled ocean-atmosphere system. Meteor. Atmos. Phys., 56, 33-55.

— active systems. Quart. J. Roy. Meteor. Soc., 118, 877-926.

Woodhouse, C. A., and J. T. Overpeck, 1998: 2000 years of drought variability in the central United States. Bull. Amer. Meteor. Soc., 79, 2693-2714.

Yiou, P., K. Fuhrer, L. D. Meeker, J. Jouzel, S. Johnsen, and P. A. Mayewski, 1997: Paleoclimatic variability inferred from the spectral analysis of Greenland and Antarctic ice core data. $J$. Geophys. Res., 102, $26441-26454$.

Yu, Z., and E. Ito, 1999: Possible solar forcing of century-scale drought frequency in the northern Great Plains. Geology, 27, 263-266.

Yuan, F., B. K. Linsey, S. P. Lund, and J. P. McGeehin, 2004: A 1200 year record of hydrologic variability in the Sierra Nevada from sediments in Walker Lake, Nevada. Geochem. Geophys. Geosyst., 5, Q03007, doi:10.1029/2003GC000652.

Zhang, Y., J. M. Wallace, and D. S. Battisti, 1997: ENSO-like interdecadal variability: 1900-93. J. Climate, 10, 1004-1020. 